\title{
MEDENÎ USÛL HUKUKUNDA HÜKMÜN TAMAMLANMASI (HMK m. 305/A)
}

\author{
COMPLETION OF JUDGEMENT IN CIVIL PROCEDURE LAW
}

\author{
Derya BELGIN GÜNEŞ*
}

Makale Bilgi

Gönderi: 27/01/2021

Kabul : 21/04/2021

\section{Anahtar Kelimeler}

\section{Hükmün}

Tamamlanmasi, Tamamlayıcı Hüküm, Ek Karar,

Hukuk Muhakemeleri Kanunu Madde 305/A, 7251 Sayll Kanun.

\section{Article Info}

Received: 27/01/2021

Accepted: 21/04/2021

\section{Keywords}

Completion of the Judgement, Complementary Judgement, Additional Decision, Civil Procedure Law Article No. 305/A, Law No. 7251.
Özet https://dai.org/10.21492/inuhfd.869441 do

Türk hukukunda hükmün tamamlanması Hukuk Muhakemeleri Kanunu'nun 305/A maddesinde düzenlenmiştir. Mahkemenin, yargılamada ileri sürülmesine veya kendiliğinden hükme geçirilmesi gerekli olmasına rağmen hakkında tamamen veya kısmen karar vermediği hallerde, asıl karardaki bu eksiklikler sonradan tamamlanabilir. Hükmün tamamlanması için taraflardan birinin talebi gereklidir. Hükmün tamamlanması talebi mahkemece kabul edilirse, hüküm ek bir karar vermek suretiyle tamamlanır. Hükmün tamamlanması düzenlemesinin amacı, eksik olan nihaî kararların tamamlanmasını sağlamaktır. Hükmün tamamlanması yoluyla mahkeme kararının düzeltilmesi veya değiștirilmesi mümkün değildir. Hükmün tamamlanması eksik hükmü veren mahkemeden talep edilir. Bu yola dilekçe ile başvurulur. Mahkeme, kanundaki şartlar altında hükümde eksik bırakılmış bir husus olduğunu tespit ederse, tamamlama talebinin kabulüne karar verir. Hükmün tamamlanmas1 talebinin mahkemece kabul edilmesi üzerine "tamamlayıc hüküm" verilir. Tamamlama talebi, gerekli şartlara sahip değilse, mahkeme tamamlama talebinin reddine karar verir. Gerek tamamlama talebinin kabulü (tamamlayıcı hüküm) gerek tamamlama talebinin reddi kararları ek karar niteliğindedir. Hukuk Muhakemeleri Kanunu'nun 305/A maddesinin 1. fikrasının 2. cümlesine göre, tamamlama talebi üzerine verilen kararlara karşı kanun yolları açıktır.

\begin{abstract}
The completion of the judgement in Turkish law is regulated in Article 305/A of the Code of Civil Procedure. These deficiencies in the essential decision may be completed later in cases where the court does not give full or partial ruling about it, although it is required to be submitted in the trial or to be adjudicated ex officio. The request of one of the parties is required for the completion of the judgement. If the request for the completion of the judgement is accepted by the court, the judgement is completed by making an additional decision. The purpose of the regulation on the completion of the judgment is to ensure the completion of the missing final decisions. It is not possible to rectify or change the court decision by completing the judgement. The completion of the judgement is requested from the court that gave the missing judgement. This method is applied with a petition. If the court finds that there is something missing in the judgement under the conditions of the law, it decides to accept the request for completion. Upon acceptance of the request for completion of the judgement by the court, a "complementary judgement" is given. If the request for completion does not meet the required conditions, the court decides to refuse the request for completion. Both the acceptance of the request for completion (complementary judgement) and the rejection of the request for completion are additional decisions. According to the 2 nd sentence of the 1 st paragraph of the article 305/A of the Civil Procedure Law, legal remedies are open against the decisions made upon the request for completion.
\end{abstract}




\section{GİRIS}

Hukuk Muhakemeleri Kanunu (HMK)'na 7251 say1lı Kanun' ${ }^{1}$ ile 305/A maddesi eklenmiştir. Söz konusu madde ile nihaî kararın verilmesinden sonra hükmün tamamlanması imkânı getirilmiştir. Düzenleme şöyledir: "Taraflardan her biri, nihâ̂ kararın tebliğinden itibaren bir ay içinde, yargilamada ileri sürülmesine veya kendiliğinden hükme geçirilmesi gerekli olmasina rağmen hakkında tamamen veya kismen karar verilmeyen hususlarda, ek karar verilmesini isteyebilir. Bu karara karşı kanun yoluna başvurulabilir."

Hukukumuzda ilk derece mahkemesi hâkimi nihaî karar verip dosyadan el çektikten sonra maddi hataların düzeltilmesi için tashih (HMK m.304) ve açık olmayan veya çelişkili ifadelerin açılanması için tavzih (HMK m.305) kurumları yer almaktaydı. Bu düzenleme ile bunların yanına hükümdeki eksikliklerin giderilmesi için hükmün tamamlanması kurumu da eklenmiştir. Esasen bir hükmün tamamlanması müessesesi, hukukumuza tamamen yabancı değildir. Çünkü tahkim yargılamasında hakemlerce verilen hükmün tamamlanmasına imkân veren düzenleme 6100 sayılı Hukuk Muhakemeleri Kanunu ile birlikte usul hukukumuza girmiştir (HMK m.437, IV). Dolayısıyla hükmün tamamlanması kurumunun Türk hukukunda Hukuk Muhakemeleri Kanunu'nun yürürlüğe girdiği 1 Ekim 2011 tarihinden beri mevcut olduğu rahatlıkla söylenebilir. Buna karşılık 1086 sayılı Hukuk Usulü Muhakemeleri Kanunu döneminde ne mahkeme kararı ne de hakem kararının tamamlanmasına ilişkin bir düzenleme bulunmaktaydı.

Aşağıda medenî usûl hukukumuza mahkeme kararları bakımından getirilen hükmün tamamlanması kurumu incelenmektedir. Çalışmamızda hükmün tamamlanmasının şartları, usûlü, verilen kararın hukukî niteliği, kanun yollarına başvuru ile ilişkisi ve tamamlayıcı hükme karşı kanun yollarına gidilmesi ve son olarak zaman bakımından uygulanma konuları işlenmektedir. İlgili bahislerde yeri geldikçe ve ihtiyaç görüldükçe Alman, İsviçre ve Avusturya hukukları hakkında da açıklama yapılmaktadır.

\section{HÜKMÜN TAMAMLANMASI HAKKINDA GENEL BÍLGILER}

\section{A. Hukukumuzda Hükmün Tamamlanmasına İlişkin Düzenlemeler}

Türk hukukunda devlet mahkemelerindeki yargılama açısından hükmün tamamlanması esas itibarıyla Hukuk Muhakemeleri Kanunu'nun 305/A maddesinde düzenlenmiştir. Buna göre, mahkemenin, yargılamada ileri sürülmesine veya kendiliğinden hükme geçirilmesi gerekli olmasına rağmen hakkında tamamen veya kısmen karar vermediği hallerde, asıl karardaki bu eksiklikler sonradan tamamlanabilir. Aynı maddenin içeriğinden açıkça anlaşıldığ 1 üzere, hükmün tamamlanması için öncelikle taraflardan birinin talebi gereklidir. Eğer taraflardan birinin hükmün tamamlanması yönündeki talebi kabul edilirse, mahkeme bunun gereğini bir ek karar vermek suretiyle yerine getirir.

Hükmün tamamlanması usûlü, Hukuk Muhakemeleri Kanunu'nun 7251 sayılı Kanun'la değiş̧irilmiş bulunan 306. maddesinde düzenlenmiş̦ir. Buna göre; hükmün tamamlanması, kararı veren mahkemeden istenir. Tamamlama dilekçesine tarafların sayısı kadar nüsha eklenir ve dilekçenin bir nüshası karşı tarafa tebliğ edilir. Karşı taraf, mahkeme tarafından belirlenen cevap süresi içerisinde tamamlama talebine cevap verebilir. Karşı tarafin cevap dilekçesi, tamamlama talebinde bulunan kişiye tebliğ edilir. Mahkeme tamamlama talebi üzerine incelemesini kural olarak dosya üzerinden yapar, gerekli görürse tarafları sözlü açıklamalarını yapmak üzere davet edebilir. Dosya üzerinden inceleme yapılması için, karşı tarafın tamamlama dilekçesine cevap vermiş olması zorunlu değildir. Mahkeme tamamlama talebini kabul ederse, Hukuk Muhakemeleri Kanunu'nun 304. maddesinin 2. fikrasına göre işlem yapar. Buna göre mahkeme, tamamlanan hususlarla ilgili kararı, asıl kararın mahkemede bulunan nüshaları ile verilmiş olan suretlerinin altına veya bunlara eklenecek ayrı bir kâğıda yazarak imzalar ve mühürler.

Hukuk Muhakemeleri Kanunu'nda hükmün tamamlanması kurumu, sistematik açıdan hükmün tashihi ve tavzihi ile beraber beşinci kısmın ikinci bölümünde yer almıştır. Hükmün tamamlanması ile hükmün tashihi ve tavzihi taşıdıkları ortak özellikler nedeniyle bu bölüm altında düzenlenmiştir. İlk olarak, hükmün tashihi, tavzihi ve tamamlanması ancak mahkeme dosyadan el çektikten sonra bir başka deyişle nihaî kararın verilmesinden sonra başvurulabilen yollardır. İkinci olarak, bu üç yolun her biri için mahkemenin mutlaka ek karar vermesi gerekir.

\section{B. Hükmün Tamamlanması Yolunun Genel Özellikleri}

Hükmün tamamlanması düzenlemesinin amacı, eksik olan nihâ̂ kararların tamamlanmasını sağlamaktır. Bu amacı göz önüne alındığında, hükmün tamamlanması etkin hukukî himayenin

${ }^{1}$ Hukuk Muhakemeleri Kanunu ile Bazı Kanunlarda Değişiklik Yapılması Hakkında Kanun, RG: 28.7.2020, S. 31199. 
sağlanmasına hizmet eder ${ }^{2}$. Hukuk Muhakemeleri Kanunu'nun 305/A maddesinin hukukumuza girmesinden önceki dönemde, mahkemece karar verilmesi unutulan talepler hakkında yalnızca kanun yollarına başvurmak mümkündü․ Unutulan talepler hakkında şartları sağlamadığı için hükmün tashihi veya tavzihi yoluna gidilmesi de mümkün değildi' ${ }^{4}$. Bu nedenle özellikle kanun yolu süresi kaçırılıp kesinleşmiş veya kesin olarak verilmiş nihaî kararlar bakımından mahkemece karar verilmesi unutulan hususlar hakkında hükmün tamamlanması imkânı bulunması etkin hukukî himaye açısından oldukça yerindedir.

Hükmün tamamlanması yoluyla önceki mahkeme kararının düzeltilmesi veya değiştirilmesi mümkün değildir ${ }^{5}$. Hatalı kararlar, şartları varsa kanun yolları ile veya hükmün tashihi yoluyla düzeltilebilir ${ }^{6}$. Buna karşılık, mahkemenin nihaî kararının hem tashih edilmesi hem de tamamlanması gerekiyorsa, bu iki yola aynı anda başvurulması mümkündür?

Hükümde eksik kalan hususlar tamamlanırken, asıl karar ile çelişen bir kararın verilmesi mümkün değildir. Aksi halde, bu çelişki artık kanun yolu aşamasında giderilebilir. Örneğin yargılama giderleri hakkında karar verilmesi unutulmuş ise, tamamlayıcı hükümde yargılama giderleri asıl kararda davayı kazanan tarafa yükletilemez.

Hükmün tamamlanması kurumunun hukukî niteliği konusunda kanunda açık bir düzenleme bulunmamaktadır. Bununla birlikte söz konusu kurumun hukukî niteliği dar ve teknik anlamda kanun yolu değildir. Zira hükmün tamamlanması, dar ve teknik anlamda kanun yollarının genel özellikleri olan ne aktarıcı ne de erteleyici etkiye sahiptir ${ }^{8}$. Hükmün tamamlanması aktarıcı etkiye sahip değildir. Çünkü hükmün tamamlanması, üst mahkemeden değil, asıl kararı veren mahkemeden talep edilir. Hükmün tamamlanmasının erteleyici etkisi de yoktur. Çünkü bu yola başvuru hükmün kesinleşmesini ertelemez; hatta başvuru süresi dolmadığı müddetçe kesinleşmiş mahkeme kararları için de hükmün tamamlanması talep edilebilir. Sonuç itibarıyla nihaî bir karara karşı başvuru imkânı sunması nedeniyle hükmün tamamlanmasının hukukî çare niteliğinde olduğu söylenebilir.

Dar ve teknik anlamda kanun yollarında (istinaf ve temyiz) mahkeme kararlarının üst mahkemece maddi ve hukukî açıdan denetimi yapılır. Ayrıca bu kanun yolları, mahkemelerce hukuk kurallarının uygulanmasında birliğin sağlanmasını amaçlar ${ }^{9}$. Hükmün tamamlanması kanun yolu olmadığından bu amaçlar karşımıza çıkmaz. Hükmün tamamlanmasının kanun yolu niteliğinde olmayıp hukukî çare kabul edilmesinin önemli bir diğer sonucu anayasa şikâyeti bakımından görülür. Alman Anayasa Mahkemesi, anayasa şikâyetinin tali nitelikte olduğu ve hukukî çarelerin de tüketilmesi gerektiği gerekçesiyle bu yola başvurmadan önce, şartları mevcutsa hükmün tamamlanmasının tüketilmesi gerektiğine karar vermiştir ${ }^{10}$. Bizim hukukumuz bakımından da Anayasa Mahkemesi’ne bireysel başvuru yapmadan önce başvuru yollarının tüketilmesi gerektiğinden, ilgililerin hükmün tamamlanması yolunu tükettikten sonra bu yola başvurulması gerekir. Her ne kadar Anayasa'nın 148. maddesinin 3. fikrasında "olağan kanun yollarının tüketilmesi” şartı bulunsa da, 6216 sayılı Anayasa Mahkemesinin Kuruluşu ve Yargılama Usulleri Hakkında Kanun'un 45. maddesinin 2. fikrası açıkça "yargısal başvuru yolları”nın tüketilmesinden bahsetmektedir.

\footnotetext{
2 PRÜTTING, Hanns/GEHRLEIN, Markus: ZPO Kommentar, 2. Auflage, Köln, 2010, §321, Kn. 1; STEIN, Friedrich/JONAS, Martin: Kommentar zur Zivilprozessordnung, 22. Auflage, Tübingen, 2013, §321, Kn. 1; PEKCANITEZ, Hakan/ATALAY, Oğuz/ÖZEKES, Muhammet: Medenî Usûl Hukuku (Usûl), 8. Bası, İstanbul, 2020, s.435.

${ }^{3}$ Hukuk Muhakemeleri Kanunu ile Bazı Kanunlarda Değişiklik Yapılması Hakkında Kanun Teklifi (2/2735) ve Adalet Komisyonu Raporu, HMK m.305/A’nın gerekçesi, https:/www.tbmm.gov.tr/sirasayi/donem27/yil01/ss216.pdf (Erişim tarihi: 1.10.2020), s.17; BUDAK, Ali Cem/KARAASLAN, Varol: "7251 Sayılı Kanunla Hukuk Muhakemeleri Kanunu'nda Yapılan Değişiklikler”, İBD, 94(5), 2020, s.25; BUDAK, Ali Cem/ KARAASLAN, Varol: Medenî Usûl Hukuku, 4. Bası, Ankara, 2020, s.307.

${ }^{4}$ KURU, Baki: Medeni Usûl Hukuku El Kitabı, C. II, Ankara, 2020, s.1585; ALANGOYA, H. Yavuz/YILDIRIM, M.Kâmil/DEREN-YILDIRIM, Nevhis: Medeni Usûl Hukuku, 7. Bası, İstanbul, 2009, s.591-592; ATALI, Murat: Pekcanıtez Usûl-Medenî Usûl Hukuku, C. III, İstanbul, 2017, s.2005; “...Tavzih yolu ile verilen hüküm değiștirilemeyeceği gibi, unutulmuş talepler hakkında da bir karar verilip hükme ekleme yapılamaz...” 2. HD, 24.9.2012, E. 2011/11250, K. 2012/22079 (Lexpera).

${ }^{5}$ THOMAS, Heinz/PUTZO, Hans: Zivilprozessordnung, München, 2016, §321, Kn. 1; PRÜTTING/GEHRLEIN, §321, Kn. 1; BAUMBACH, Adolf/LAUTERBACH, Wolfgang: Becksche Kurz Kommentare Zivilprozessordnung, 62. Auflage, München, 2004, §321, Kn. 2; FASCHING, Hans W.: Kommentar zu den Zivilprozeßgesetzen, 2. Auflage, Wien, 2004, §423, Kn. 4.

${ }^{6}$ PRÜTTING/GEHRLEIN, $\$ 321$, Kn. 1.

${ }^{7}$ THOMAS/PUTZO, $\$ 321$, Kn. 1 .

${ }^{8}$ PEKCANITEZ/ATALAY/ÖZEKES, Usûl, s.436.

9 PEKCANITEZ/ATALAY/ÖZEKES, Usûl, s.467-468; ATALI Murat/ERMENEK, İbrahim/ERDOĞAN, Ersin: Medeni Usûl Hukuku, 3. Bas1, Ankara, 2020, s.600-601; BUDAK/KARAASLAN, Usûl, s.368.

10 BVerfG, 27.4.2000, 1 BVR 2077/99 (NJW-RR 2000，1664); BAUMBACH/LAUTERBACH， §321，Kn. 10; STEIN/JONAS, §321, Kn. 29.
} 
Anayasa Mahkemesi, bir başvurucunun hükmün tashihi yoluna başvurup talebinin reddedilmesinden sonra bireysel başvuru yapmasını kabul edilemez bulmuştur. Yüksek Mahkeme, hükmün tashihi bakımından herhangi bir süre sınırı bulunmadığı için, bu yolun tüketilmesinden sonra bireysel başvuru süresinin başlayacağının kabul edilmesinin süresiz bireysel başvuru yapabilme yolunu açabileceğine ve böyle bir uygulamanın hukuki belirlilik ilkesi ve bireysel başvurunun mahiyeti ile bağdaşmayacağına karar vermiştir"1. Söz konusu kararında Anayasa Mahkemesi "Avrupa İnsan Hakları Mahkemesi de kesin bir süre sinırı bulunmayan hukuk yollarının belirsizlik yaratacağını ve Avrupa İnsan Hakları Sözleşmesi'nin 35. maddesinde yer alan altı aylık süre kuralını işlevsiz kılacă̆ını içtihatlarında belirtmiştir (Williams/Birleşik Krallık (k.k.), B. No: 32567/06, 17/2/2009)" ifadelerine de yer vermiştir. Bu karardan yola çıkarak, hükmün tamamlanmasına başvuru süresinin açık bir biçimde mahkemenin nihaî kararının tebliğinden itibaren bir ay olması karşısında, hükmün tashihindeki gibi belirsizliğe yol açmayacağı söylenebilir. Sonuç itibarıyla, hükmün tamamlanması yoluna başvurulması neticesinde verilen kararın kesinleşmesinden itibaren işletilecek otuz günlük bireysel başvuru süresi içerisinde temel hak veya özgürlüğünün ihlal edildiği iddiası ile Anayasa Mahkemesi'ne başvurulması kanaatimizce mümkündür.

\section{Karşılaştırmalı Hukukta Hükmün Tamamlanmasına İlişkin Düzenlemeler}

\section{Alman Hukukunda}

Alman Medenî Usûl Kanunu'nda (Zivilprozessordnung/ZPO) hükmün tamamlanmas1, 321. paragrafta düzenlenmiştir. Söz konusu düzenleme şöyledir:

"(1) Taraflardan birinin önceden tespit edilmiş veya sonradan düzeltilmiş vakıalar çerçevesinde ileri sürdüğ̈̈ asıl veya tali talep yahut yargllama giderleri nihaî kararda tamamen ya da kısmen unutulmuşsa; hüküm, talep üzerine verilen sonraki bir kararla tamamlanir.

(2) Ek karar hükmün tebliğinden itibaren iki hafta içerisinde dilekçe ile talep edilir.

(3) Hükmün asli talebinin tamamlamasına ilişkin bir talep varsa, sözlü yargllama için bir duruşma günü tayin edilir. Talep edenin karşı tarafina, duruşma gününe iliş̧kin davetiye ile beraber talebi içeren dilekçe de tebliğ edilir. Hükmün tali talebinin veya yargılama giderinin tamamlanmasina ilişkin talep hakkında, uyuşmazlığın konusu sözlü yargılamayı gerektirmiyorsa, sözlü yargllama yapılmaksızın karar verilebilir; § 128 fikra 2 cümle 2 geçerlidir.

(4) Sözlü yargılamanın konusu, yalnızca uyuşmazlı̆̆ın yerine getirilmemiş kısmıdır."

Bunun yanında ZPO § 518'de hükmün tamamlanması halinde istinafa başvuru düzenlenmiştir. Buna göre "İstinafa başvuru süresi içerisinde, hüküm ek bir karar ile tamamlanırsa, ek kararın tebliğinden itibaren ilk verilen karara karşı istinafa başvuru süresi yeniden işlemeye başlar. Her iki karara karşı aynı taraf istinafa başvurursa, iki istinaf incelemesi birbirini bağlar." ZPO § 716 düzenlemesinde ise geçici icra edilebilirlik (vorläufige Vollstreckbarkeit) hakkında karar verilmemişse, $\S 321$ 'e göre hükmün tamamlanmasının uygulanacağı öngörülmüştür.

2. Avusturya Hukukunda

Alman hukukuna oldukça benzer şekilde Avusturya Medenî Usûl Kanunu (österreichische Zivilprozessordnung/öZPO) $§$ 423'te hükmün tamamlanması düzenlenmiştir. Söz konusu düzenlemeye göre;

"(1) Hükümde hakkinda karar verilmesi gereken bir talep unutulmuş ise veya taraflardan biri tarafindan karşılanması istenen yargılama gideri hakkında hiç karar verilmemiş veya eksik karar verilmişse, hüküm ek bir karar ile tamamlanır (Tamamlayıcı hüküm).

(2) Tamamlama talebi, karar veren mahkemeden hükmün tebliğinden itibaren on dört gün içerisinde istenir.

(3) Mahkeme gerekli hallerde, önceki sözlü yargllamanın yapılmasına karar verir. Bu duruşma uyuşmazlığın yerine getirilmeyen kismı ile sinırlıdır. Tamamlama talebi, karar (Beschluss) ile reddedilir."

Avusturya Medenî Usûl Kanunu'nda tamamlama talebi üzerine kanun yoluna başvurulmasının etkisi de $\S 424$ 'te düzenlenmiştir. Buna göre, "Hükmün tamamlanması yargılamasl, kanun yollarına başvuru üzerinde herhangi bir etki doğurmaz."

\section{3. İsviçre Hukukunda}

İsviçre hukukunda, Alman veya Avusturya hukuklarında olduğu gibi hükmün tamamlanmasına ilişkin herhangi bir kanunî düzenleme bulunmamaktadır. Kanunî bir düzenleme bulunmadığı için, hükmün sonradan tamamlanması kabul edilmemektedir. İsviçre hukukuna göre, mahkeme kararının en azından taraflardan biri tarafından tebliğ alınması, kural olarak mahkemenin kararını kaldırmasına, değiştirmesine ve tamamlamasına engel olur. Bu kural "lata sententia iudex desinit esse iudex" ("Hüküm verildikten sonra hâkimin hâkimliği kalmaz; hüküm verilmekle dosyadan el çekilir ve artık

${ }^{11}$ Setenay Çeçeren, 16.6.2016, Başvuru No. 2014/5669, §44. 
dosyaya el atılamaz") ilkesi ile açıklanır. Fakat mahkeme oylama ile tebliğ arasında kararından dönebilir ve yeni bir çoğunluk kararı ile hükmünü değiş̧tirebilir. Bu ilkenin bazı istisnaları da bulunmaktadır. Tavzih, tashih, yargılamanın yenilenmesi, değişiklik davası ve kararın üst mahkemede kaldırılması veya değiştirilmesi halinde bu ilke uygulanmaz ${ }^{12}$.

\section{HÜKMÜN TAMAMLANMASININ ŞARTLARI}

\section{A. Nihaî Bir Mahkeme Kararının Bulunması}

Kanun koyucu, Hukuk Muhakemeleri Kanunu'nun 305/A maddesini kaleme alırken "hüküm" ifadesini kullanmayı tercih etmiştir. Medenî usûl hukukunda "hüküm" kavramından anlaşılması gereken, esasa ilişkin nihaî kararlardır (HMK m.294, I, 2. cümle). Hukuk Muhakemeleri Kanunu sistematik açıdan nihaî kararlara ilişkin düzenlemeler yaparken "hüküm" (esasa ilişkin nihâ̂ karar) kavramını esas alır $^{13}$. Hükme ilişkin hususlar ise, niteliğine aykırı düşmedikçe, usule ilişkin nihaî kararlar hakkında da uygulanır (HMK m.294, VI). Dolayısıyla Hukuk Muhakemeleri Kanunu'nun 305/A maddesi açısından yalnızca esasa ilişkin nihaî kararlar için hükmün tamamlanması yoluna başvurulmaz. Esasa ilişkin nihaî kararların yanı sıra, usûle ilişkin nihaî karar veya esas hakkında karar verilmesine yer olmadığı kararında da eksiklik bulunabilir. Örneğin derdestlik itirazı nedeniyle davanın reddi kararında yargılama giderlerine hükmedilmesi unutulmuşsa, bu karar tamamlanabilir. Başka bir örnek olarak ileri sürülen birden fazla talebin tamamı için karar verilmesine yer olmadığ 1 kararı verilmesi gerekirken biri hakkında karar verilmemişse tamamlanabilmesi verilebilir. Sonuç itibarıyla Hukuk Muhakemeleri Kanunu'nun 305/A maddesinde yalnızca "hüküm" ifadesi yer alsa da mahkeme tarafından verilen tüm nihâ̂ kararlar bakımından söz konusu kuralın uygulanması mümkündür. Bir başka deyişle hükmün tamamlanması yoluna başvurulması için, öncelikle nihaî bir mahkeme kararının bulunması gerekir.

Kural olarak, nihaî kararın verilmesi ile hâkim dosyadan elini çeker. Dosyadan el çekmek, üst mahkeme tarafindan yapılan inceleme sonucunda dosya mahkemeye geri gönderilmediği müddetçe, mahkemenin dosyayı tekrar ele alamamasını ifade eder. Bu kuralın çeşitli istisnaları bulunmaktadır. Örneğin, ilk derece mahkemesi istinaf dilekçesinin reddine (HMK m.346) dosyadan el çekmiş olsa da karar verebilir. Keza başka bir örnek olarak hükmün verilmesinden sonra davadan feragat veya dava kabul edilmiş ise ilk derece mahkemesi veya istinaf mahkemesinin, kanun yoluna başvurulmuş olsa da, bu konuda ek bir karar vermesi gösterilebilir (HMK m.310, II). Hükmün tamamlanması da hâkimin dosyadan el çekmesinin istisnalarından biridir. Buna göre, mahkeme, nihaî karar vermiş olmasına rağmen kararda eksiklik bulunması halinde, tamamlama talebini kabul veya reddederek ek bir karar verebilir.

Hükmün tamamlanmasına başvurulacak nihâi kararın türü önem arz etmez. Eksiklik söz konusu ise, esasa ilişkin bir nihaî kararın tamamlanması talep edilebileceği gibi, usûle ilişsin bir nihaî kararın veya karar verilmesine yer olmadığı kararının da tamamlanması mümkündür. Önemli olan, Hukuk Muhakemeleri Kanunu'nun 305/A maddesinde ifade edilen nitelikte bir eksiklik bulunmasıdır. Hatta tamamlayıcı hükmün kendisi de şartları varsa tamamlanabilir ${ }^{14}$. Keza çekişmesiz yargı kararlarına karşı da hükmün tamamlanması yoluna başvurulabilir.

Alman hukukuna göre, geçici hukukî himaye tedbiri kararlarına karşı da hükmün tamamlanmasına başvurulması kabul edilmektedir. Örneğin ihtiyati tedbir kararı verilirken teminatın miktarı hakkında karar verilmesi unutulmuşsa, bu kararın tamamlanması mümkündür ${ }^{15}$. Ancak hukukumuz bakımından bu sonuca varılması kanaatimizce mümkün değildir. Çünkü hükmün tamamlanmasının uygulanabilmesi için nihaî kararın varllğı zorunlu olduğundan ve ihtiyati tedbir üzerine verilen kararlar bu nitelikte olmadığından ihtiyati tedbir üzerine verilen kararlara karşı hükmün tamamlanması istenemez. Hukuk Muhakemeleri Kanunu tarafindan ihtiyati tedbir ve ihtiyati haciz kararlarının nihaî karar olarak kabul edilmediğini, HMK m.341, I'de istinafa başvurulacak kararları düzenlerken nihaî kararlardan ayrı olarak bu kararları belirtmesinden anlaşılmaktadır. İhtiyati tedbir kararlarına, genel olarak geçici hukukî himaye tedbiri kararlarına karşı hükmün tamamlanması yoluna başvurulması için kanunda özel bir düzenleme bulunması zorunludur. Bu konuda Avusturya Medeni Usul Kanunu'nda özel bir düzenleme yer almaktadır (öZPO § 430).

Mahkeme kararının kesin nitelikte veya kesinleşmiş olması hükmün tamamlanmasına engel teşkil etmez. Hukuk Muhakemeleri Kanunu'nun 305/A maddesinde yer alan bir aylık süre dolmadığ 1

\footnotetext{
${ }^{12}$ STAEHELIN, Adrian/STAEHELIN, Daniel/GROLIMUND, Pascal: Zivilprozessrecht, 2. Auflage, Zürich, 2013, s.452.

${ }^{13}$ ATALI/ERMENEK/ERDOĞAN, s.554.

${ }^{14}$ FASCHING, $\$ 423$, Kn. 6.

${ }^{15}$ PRÜTTING/GEHRLEIN, §321, Kn. 10.
} 
sürece, mahkeme kararı kesin olarak verilmiş veya kanun yoluna başvurulmadığı için karar kesinleşmiş ise hükmün tamamlanması yoluna başvurulabilir.

Hükmün tamamlanması imkânı, yalnızca ilk derece mahkemesi kararları için değil, eksik hükmü veren her derecedeki mahkeme için söz konusudur ${ }^{16}$. İstinaf ve temyiz mahkemesi kararları için de Hukuk Muhakemeleri Kanunu'nun 305/A maddesindeki şartlarla tamamlanmasının talep edilmesi mümkündür.

Ara kararlarında yer alan eksikliklerin tamamlanması için Hukuk Muhakemeleri Kanunu'nun 305/A maddesi uygulama alanı bulmaz. Mahkeme tutanaklarında yer alması gereken hususlar Hukuk Muhakemeleri Kanunu'nun 154. maddesinin 3. fikrasında tek tek sayılmış olmakla beraber, ara kararının tamamlanmasına ilişkin mevzuatımızda açık bir düzenleme bulunmamaktadır. Ara kararında taraflarca ileri sürülen veya mahkemece kendiliğinden karar verilmesi gereken hususlarda eksiklik bulunması halinde mahkeme bunu re'sen veya talep üzerine tamamlayabilir. Cebri icra yoluyla yerine getirilmesinin istenebileceği ara kararları (örneğin, tedbir nafakası kararı) bakımından da aynı sonuca ulaşmak mümkündür. Hükmün tamamlanması yolu için nihaî karar bulunması zorunlu olduğundan icra kabiliyeti bulunsa da farklı bir sonuca ulaşmak mümkün değildir.

\section{B. Hükümde Eksiklik Olması}

\section{Genel Olarak}

Hukuk Muhakemeleri Kanunu'nun 305/A maddesine göre, hükmün tamamlanması "yargllamada ileri sürülmesine veya kendiliğinden hükme geçirilmesi gerekli olmasina rağmen hakkında tamamen veya kısmen karar verilmeyen hususlarda" talep edilebilir. Hükmün tamamlanmasının konusunu, mahkemenin nihaî olarak karar vermesi gerektiği halde eksik bıraktığ hususlar teşkil eder. Burada kanun koyucunun "husus"tan ne kastettiğinin belirlenmesi gerekir. Söz konusu düzenlemenin ifadesine bakarsak, "husus" yargılamada ileri sürülen veya kendiliğinden hükme geçirilen ve hakkında mahkemenin bir karar vermesi gereken bir unsurdur. "Husus" kelime anlamı itibarıyla ilk olarak "konu, madde", ikinci olarak "özellik, yön" anlamlarına gelmektedir"17. Kanaatimizce burada "husus" kelimesine sözlük anlamından farklı bir anlam yüklenmesi amacı bulunmamaktadır. Keza hükmün kapsamını düzenleyen Hukuk Muhakemeleri Kanunu'nun 297. maddesi bakımından hüküm, çeşitli "husus"lardan oluşmakta ve altı bent halinde sayılmaktadır.

Hukuk Muhakemeleri Kanunu'nun 305/A maddesi anlamında, hakkında kısmen veya tamamen karar verilmemiş olan "husus"lar, "yargılamada ileri sürülen" ve "kendiliğinden hükme geçirilen" hususlar olarak ikiye ayrılabilir. Bu iki grup "husus"u birbirinden ayıran özellik, ilkinin taraflarca ileri sürülmesi, ikincisinin mahkemece re'sen hükme geçirilmesidir.

"Yargılamada ileri sürülen husus" ifadesinden medenî usûl hukuku bakımından anlaşılması gereken "talep" kavramıdır. Bir başka ifadeyle, taraflardan birinin yargılamada ileri sürdüğü "talep" hakkında mahkeme tamamen veya kısmen karar vermemiş ise hükümde eksiklik ortaya çıkar. Alman ve Avusturya hukuklarındaki kanunî düzenlemelere ${ }^{18}$ baktığımızda da, hükmün tamamlanması yoluna başvuru için, taraflardan birini ileri sürdüğü taleplere hükümde yer verilmemiş olması gerekir.

"Kendiliğinden hükme geçirilmesi gerekli olan hususlar" bakımından ortak tek bir kavram kullanmak pek mümkün görünmemektedir. Bunlar örneğin, yargılama giderleri, kanun yolu ve süresi, hükmün hangi sıfatla verildiği gibi hükümde yer alması gereken hususlar olabilir. Yine Alman ve Avusturya hukuklarına baktığımızda, bu ikinci grup eksiklik bakımından yalnızca "yargılama gideri" göz önünde bulundurulmaktadır. Türk hukukunda ise "kendiliğinden hükme geçirilmesi gerekli olan husus" ifadesi kullanılarak, hükümdeki eksiklik, yargılama giderini de içine alacak biçimde daha geniş bir biçimde öngörülmektedir.

Hukuk Muhakemeleri Kanunu'nun 305/A maddesi anlamında mahkemenin bir talep hakkında karar vermemesinin sebebi, bunu unutmuş olmasıdır ${ }^{19}$. Bir başka deyişle mahkemenin sehven veya bilinçsiz bir şekilde, nihaî karar verirken bazı talepleri veya hususları atlamış olması gerekir. Alman hukukuna göre hâkim, bilinçli bir şekilde bazı talepler hakkında karar vermemişse, kısmî karar (ZPO § 301) söz konusu olur ${ }^{20}$. Bu şekilde mahkeme iradî olarak bir talep hakkında karar vermediği hallerde hükmün tamamlanması uygulanmaz ${ }^{21}$. Türk hukuku bakımından ise, kısmî karar verilmesine ilişkin

\footnotetext{
${ }^{16}$ FASCHING, §423, Kn. 11; RECHBERGER, Walter H./KLICKA, Thomas: Zivilprozessordnung, 5. Auflage, Wien, 2019, $\S 423$, Kn. 1; PEKCANITEZ/ATALAY/ÖZEKES, Usûl, s.436.

${ }^{17}$ Türk Dil Kurumu Güncel Türkçe Sözlük, www.sozluk.gov.tr (Erişim Tarihi: 10.12.2020).

${ }^{18}$ Bkz. I, C.

${ }^{19}$ MUSIELAK, Hans-Joachim: Kommentar zur Zivilprozessordnung, 8. Auflage, München, 2011, §321, Kn. 4.

${ }^{20}$ WIECZOREK, Bernhard/SCHÜTZE, Rolf A.: Zivilprozessordnung und Nebengesetze, Berlin, 2014, §321, Kn. 1; THOMAS/PUTZO, §321, Kn. 2.

${ }^{21}$ MUSIELAK, §321, Kn. 5; THOMAS/PUTZO, §321, Kn. 2.
} 
herhangi bir kanunî düzenleme bulunmamaktadır ${ }^{22}$. Buna karşıllk kısmî karar verilmesini yasaklayan bir kural da bulunmamaktadır ${ }^{23}$. Dolayısıyla Türk hukukunda kısmî karar verildiği, başka bir deyişle iradi olarak hâkim kararını eksik bıraktığı takdirde hükmün tamamlanması yoluna başvuru mümkün olmayacaktır.

Hükümde bulunan eksikliğin mahkemece unutulması gerekir, tarafların ileri sürmeyi unuttukları taleplerin Hukuk Muhakemeleri Kanunu'nun 305/A maddesi yoluyla tamamlanması mümkün değildir. Taraflar dava konusu uyuşmazlık ile bağlantılı bir talebi ileri sürmeyi unutmuş ve mahkeme kararı bu şekliyle kesinleşmiş ise, artık yeni bir dava açılması gerekir ${ }^{24}$.

\section{Yargılamada İleri Sürülen Talep Bakımından}

Taraflarca ileri sürülen taleplerin her birinin, mahkemenin nihaî kararında gerekçeleri ile birlikte kabul veya ret nedenlerinin yazılmaları gerekir. Mahkeme bu taleplerden biri veya birkaçı hakkında karar vermeyi unutmuşsa, hükmün verilmesinden sonra Hukuk Muhakemeleri Kanunu'nun 305/A maddesindeki şartlarla bu talepler hakkında tamamlayıcı bir karar verilebilir.

Nihaî kararın verilmesinden sonra tamamlanabilen talepler, "usûlî talepler"dir. Neticei talebe dâhil olan bir talep (yahut onun bir kısmı) hakkında karar verilmemiş ise ancak bunun tamamlanması söz konusu olur; yoksa talep sonucunu etkileyecek bir iddia yahut savunma sebebinin (vakıasının) hüküm kurulurken gözetilmemesi suretiyle karar verilmişse, bu eksikliğin giderilmesi hükmün tamamlanması yoluyla sağlanamaz. Kısaca, hakkında karar verilmemiş olan maddi hukuka ait taleplerin tamamlanması mümkün değildir ${ }^{25}$. Örneğin, davada ileri sürülen talep içerisinde yer alan itiraz hakkında karar verilmesi unutulmuşsa, hükmün tamamlanması ile bu hatanın giderilmesi mümkün değildir, ancak bu karar kanun yollarına götürülebilir ${ }^{26}$. Taraflardan birinin ileri sürdügü iddia veya savunma vasitaları mahkeme tarafından atlanmışsa, bu eksiklik sadece kanun yollarında ileri sürülebilir, hükmün tamamlanması söz konusu olmaz. Bu nedenle örneğin davalının takas itirazı ${ }^{27}$, hapis hakk1 ${ }^{28}$ veya edimin ifa edildiği iddiası ${ }^{29}$ ile ilgili karar verilmesi unutulmuşsa, hükmün tamamlanmasına başvurulamaz. Çünkü maddi hukuka ilişskin bu gibi savunmalar hakkında tamamlayıcı bir karar verilecek olursa, asıl kararın etkisiz hale getirilmesi veya değiştirilip düzeltilmesi sonuçlarından biri ortaya çıkabilir ki bunun hükmün tamamlanması yolu ile yapılması mümkün değildir. Keza teksif ilkesi kapsamında tarafların iddia ve savunmaların ileri sürebilecekleri usûl kesiti (HMK m.141) kanunen belirlenmiş olduğundan hükmün tamamlanması yoluyla bunun kabul edilmesi söz konusu ilkenin ihlali anlamına gelir.

Taraflarca ileri sürülen talebin tamamı veya bir kısmı hakkında karar verilmesi unutulmuş olabilir $^{30}$. Birden fazla talep objektif dava birleşmesi şeklinde ileri sürülmüş, fakat mahkeme bunlardan biri hakkında karar vermeyi unutmuşsa, hükmün tamamlanması talep edilebilir ${ }^{31}$. Örneğin davacı boşanma davası ile beraber çocuğun velayetinin kendisine verilmesini talep ettiği halde, mahkeme velayet hakkında bir karar vermemişse, hükmün tamamlanması mümkündür ${ }^{32}$. Talebin kısmen unutulması örneğin, mahkemenin alacağın anaparası hakkında karar vermesi ama faiz hakkında karar vermeyi unutması halinde ortaya çıkabilir ${ }^{33}$. Bu durumda alacağın faizi hakkında hüküm tamamlanarak

\footnotetext{
${ }^{22}$ Tahkim yargılaması bakımından hakemlerin kısmî karar verebilmesi mümkündür (HMK m.436, II).

${ }^{23}$ BAHADIR, Zeynep: Medenî Usûl Hukukunda Kısmî Karar, Ankara, 2018, s.62.

24 “....Hâkim, gerek talep üzerine gerek kendiliğinden karar verilmesi unutulan talep hakkinda bir karar vererek hükmü değiştiremeyeceği gibi hükmün tavzihi/tashihi yolu ile de unutulmuş talep hakkında bir karar verip, bunu hükme ekleyemez. Davacı vekilinin olumlu olumsuz bir karar verilmiş olmayan talep hakkında hükümden sonra istinaf kanun yoluna başvurmadiğl, bu sebeple davacı yönünden hükmün kesinleştiği, ancak olumlu olumsuz bir karar verilmediğinden talep hakkında gerektiği takdirde yeniden dava açma hakkı mevcut bulunmaktadır...” İst BAM, 12. HD, 24.9.2019, E. 2019/1310, K. 2019/1158 (Lexpera).

${ }^{25}$ WIECZOREK/SCHÜTZE, §321, Kn. 6.

${ }^{26}$ MUSIELAK, \$321, Kn. 4; THOMAS/PUTZO, \$321, Kn. 2.

${ }^{27}$ MUSIELAK, §321, Kn. 4; STEIN/JONAS, §321, Kn. 7.

${ }^{28}$ ROSENBERG, Leo/SCHWAB, Karl Heinz/GOTTWALD, Peter: Zivilprozessrecht, 18. Auflage, München, 2018, §61, Kn. 24; MUSIELAK, §321, Kn. 4; PRÜTTING/GEHRLEIN, §321, Kn. 3; THOMAS/PUTZO, §321, Kn. 2.

${ }^{29}$ PRÜTTING/ GEHRLEIN, $\$ 321$, Kn. 3.

30 PRÜTTING/GEHRLEIN, $\$ 321, \mathrm{Kn} .3$.

31 PEKCANITEZ, Hakan/ATALAY, Oğuz/ÖZEKES, Muhammet: "Hukuk Muhakemeleri Kanunu'nda Değişiklik Yapılmasına Dair 7251 sayılı Kanun Hakkında Değerlendirme” (7251 sayılı Kanun), TBBD, 150, 2020, s.280.

${ }^{32}$ HMK m.305/A'dan önceki dönemde Yargıtay bu konuda tavzih kararı verilemeyeceğine karar vermiştir, “....Mahkemece tavzih talebi kabul edilmiş müşterek çocukların velayetinin davacı-davalı anneye verilmesine karar verilerek tavzih yolu ile hükme eklenilmiştir... Hükümde unutulan veya gösterilmemiş olan bir hususun tavzih (HMK m.305) yoluyla hükme ilave edilmesi mümkün değildir...” 2. HD, 2.6.2016, E. 2016/10007, K. 2016/10960 (YILMAZ, Ejder: Hukuk Muhakemeleri Kanunu Şerhi, C. III, Ankara, 2017, s.2984).
}

${ }^{33}$ WIECZOREK/SCHÜTZE, §21, Kn. 7. 
ek bir karar verilebilir. Örneğin nafakanın artırılması ile ilgili hükmün hangi tarihten itibaren geçerli olduğunun yazılmamış olması sonradan tamamlanabilir ${ }^{34}$. Bir başka örnek olarak, dava arkadaşlarından biri hakkında karar verilmesinin unutulması da verilebilir ${ }^{35}$. Keza davalının açtığı karşı dava hakkında karar verilmesi unutulmuşsa, hükmün tamamlanması yoluna başvurulabilirr ${ }^{36}$. Birleşen dava hakkında mahkeme karar vermeyi unutmuş ise, hükmün tamamlanması mümkündür ${ }^{37}$. Fakat mahkemenin talep edilenden fazlasına karar vermiş olması halinde, bu karar hükmün tamamlanması yolu ile düzeltilemez ${ }^{38}$.

Hakkında karar verilmesi unutulan talep, asli talep veya tali talep olabilir ${ }^{39}$. Örneğin, terditli davada, mahkeme asli talebin reddine karar vermekle birlikte tali talep hakkında bir karar vermemişse, hükmün tamamlanması yoluna başvurulabilir ${ }^{40}$. Buna karşılık davacı seçimlik dava açmış ve bu taleplerinden biri hakkında karar verilmemiş olması, seçimlik davanın hukukî niteliği karşısında hükmün tamamlanmasını gerektirmez ${ }^{41}$.

Hükmün tamamlanması yoluna başvurulabilmesi için unutulan talep hakkında hem hüküm fikrasında bir karar bulunmaması hem de hükmün gerekçesinde bu talebe ilişkin herhangi bir ifadenin yer almaması gerekir ${ }^{42}$. Bir başka deyişle tamamlama talebi hiçbir zaman sadece hükmün gerekçesini tamamlamaya yönelik olamaz ${ }^{43}$. Alman ve Avusturya hukuklarında hükmün gerekçesinde talep hakkında mahkemenin görüşleri yer alıyor, fakat hüküm fikrasında talebin kabul veya reddedildiği belirtilmemişse, hükmün eksik olduğu değil, hatalı olduğu kabul edilir. Bu nedenle bu durumda hükmün tashihi yoluna başvurulması gerekir ${ }^{44}$. Aynı şekilde hüküm fikrasında yer alıp hakkında karar verilen taleplere ilişkin hükmün gerekçesinde herhangi bir ifade veya görüş yer almıyorsa, hükmün tamamlanması değil, hükmün tashihi yoluna gidilmelidir ${ }^{45}$. Buna karşıllk Türk hukukunda kanaatimizce açık yazı ve hesap hatası benzeri maddi hata boyutunu aşan nitelikteki hususların hükmün tashihi yolu ile düzeltilmesi mümkün değildir. Keza gerekçe ile hüküm arasındaki çelişki tavzih yolu ile de giderilemez ${ }^{46}$. Çünkü hüküm fikrasında taraflara tanınan haklar ve yüklenen borçlar, tashih veya tavzih yolu ile sınırlandırılamaz, genişletilemez ve değiştirilemez (HMK m.305, II). Söz konusu düzenleme yalnızca hükmün tavzihine ilişkin maddede düzenlenmekle birlikte, Yargitay, hem tashih hem de tavzih bakımından bu sinırlamayı uygulamaktadır ${ }^{47}$. Söz konusu durumlar ancak kanun yollarında ileri sürülebilir. Zira kısa karar ile gerekçeli karar arasındaki çelişkinin bozma nedeni olduğu Yargıtay İçtihadı Birleştirme Kararı ile de ortaya konmuştur ${ }^{48}$.

\section{Kendiliğinden Hükme Geçirilmesi Gereken Hususlar Bakımından}

Hükümde eksik bırakıldığı takdirde tamamlanması mümkün olan bir diğer grup eksiklik, kanunun ifadesiyle "kendiliğinden hükme geçirilmesi gereken hususlar"dır. Hükümde yer alması gereken hususların neler olduğu Hukuk Muhakemeleri Kanunu'nun 297. maddesinde yer alır. Ancak hükmün unsurlarının her birindeki eksiklik için tamamlama yoluna gidilmesi gerekmez. Hükmün

\footnotetext{
${ }^{34}$ UMAR, Bilge: Hukuk Muhakemeleri Kanunu Şerhi, 2. Bas1, Ankara, 2014, s.898 (yazar tarafindan bu örnek tavzihi mümkün bir hal olarak belirtilse de, hükmün tamamlanması imkânının mevcut olmadığı dönemde tavzih ile düzeltilebilecek bir eksiklik kanaatimizce değildir.).

${ }^{35}$ STEIN/JONAS, §321, Kn. 6. Doktrinde ileri sürülen aksi görüşe göre, mahkeme dava arkadaşlarından biri hakkında karar vermemiş ise, kısmî hüküm söz konusudur. Bu karar tamamlanamaz, aksine son karar (Schlussurteil) verilmesi gerekir (BAUMBACH/LAUTERBACH, $\S 321$, Kn. 5).

${ }^{36}$ PRÜTTING/GEHRLEIN, §321, Kn. 3; STEIN/JONAS, §321, Kn. 7.

${ }^{37}$ HMK m.305/A'dan önceki dönemde Yargıtay birleșen dava hakkında hüküm kurulması unutulmuş ise, tavzih ile yeni bir hüküm verilemeyeceğine karar vermiştir, 21. HD, 15.12.2014, E. 2014/21516, K. 2014/27352 (ATALI, Pekcanıtez Usûl, s.2005, dn. 100).

${ }^{38}$ MUSIELAK, $\$ 321$, Kn. 6.

39 PRÜTTING/GEHRLEIN, §321，Kn. 3; STEIN/JONAS， §321，Kn. 6; WIECZOREK/SCHÜTZE， \$321，Kn. 7; PEKCANITEZ/ATALAY/ÖZEKES, Usûl, s.435.

${ }^{40}$ FASCHING, $\$ 423$, Kn. 3.

${ }^{41}$ FASCHING, $\$ 423, \mathrm{Kn} .3$.

${ }^{42}$ THOMAS/PUTZO, $\$ 321$, Kn. 1.

${ }^{43}$ FASCHING, $\$ 423, \mathrm{Kn} .4$.

44 MUSIELAK, §321, Kn. 5; THOMAS/PUTZO, §321, Kn. 2; WIECZOREK/SCHÜTZE, §321, Kn. 11; BAUMBACH/LAUTERBACH, §321, Kn. 4; FASCHING, §423, Kn. 5.

${ }^{45}$ MUSIELAK, §321, Kn. 5; THOMAS/PUTZO, §321, Kn. 2; BAUMBACH/LAUTERBACH, §321, Kn. 4; Fasching'e göre, hüküm fikrasında talep hakkında bir karar verilmiş, gerekçede buna ilişkin hiçbir şey yer almıyorsa, bu hata yalnızca istinafta (öZPO §477, 1, 9) giderilebilir, hükmün tamamlanması uygulanmaz (FASCHING, §423, Kn. 5).

${ }^{46}$ YILMAZ, s.2989.

47 “...ne tavzih ne de tashih yoluyla, mahkeme kararında yer almayan yeni bir yükümlülügün taraflara yüklenmesi ya da bir hakkın taraflara sağlanması mümkün değildir...” 17. HD, 12.03.2018, E. 2015/8349 K. 2018/1737 (Lexpera); aynı yönde 8. HD, 25.3.2019, E. 2018/3165, K. 2019/3139 (Lexpera); 14. HD, 8.7.2020, E. 2019/3684, K. 2020/4493 (Lexpera).

${ }^{48}$ YIBK, 10.04.1992,E. 1991/7,K. 1992/4 (RG, 10.6.1992, S. 21254).
} 
tamamlanmasının tarafların talebi üzerine işletilen bir yol olduğu dikkate alındığında, hükme kendiliğinden geçirilmesi gereken hususlardan olup da taraflara yüklenen borçlar veya tanınan haklar bakımından bir eksiklik sonucu ortaya çıkarsa hükmün tamamlanması yoluna başvurulması gerekir. $\mathrm{Bu}$ tür hususlara örnek olarak yargılama giderleri, kanun yolunun açık olup olmadığ 1 , kanun yolu açıksa süresi, hükmün verildiği tarih verilebilir. Bunun dışında taraflara yüklenen borçlar veya tanınan haklar bakımından bir sonuç doğurmayan hususlarda eksiklik bulunması maddi hata niteliğini de taşıyorsa ancak hükmün tashihi yoluna başvurulabilir. Örneğin mahkemenin hangi özel mahkeme sıfatıyla verildiğinin yazılması unutulmuş ise, talep üzerine veya mahkemece re'sen düzeltilebilir ${ }^{49}$. Keza hâkimin veya zabıt kâtibinin adının yahut "Türk Milleti Adına" ibaresinin yazılmasının unutulması gibi eksiklikler hükmün tashihi yolu ile her zaman re'sen veya talep üzerine düzeltilebilir.

Kendiliğinden hükme geçirilmesi gereken hususlar dendiğinde akla ilk gelen yargılama giderleri olmaktadır. Yargılama giderlerine mahkemece re'sen karar verileceği açıkça Hukuk Muhakemeleri Kanunu'nun 332. maddesinin 1. fikrasında düzenlenmektedir. Yargilama giderlerinin mahkemece tamamı unutulmuş olabileceği gibi bir kısmı da unutulmuş olabilir. Her iki durumda da hükmün tamamlanması yoluna başvurulabilir. Keza fer'i müdahale gideri hakkında mahkeme karar vermeyi unutmuşsa, hükmün tamamlanması mümkündür ${ }^{50}$.

Yargılama gideri hakkında karar verilirken hâkimin takdir hakkının bulunduğu hallerde, hükmün tamamlanması uygulanmaz. Çünkü burada yargılama giderinin eksik verilip verilmediği sorunu değil, yargılama giderinin doğru şekilde paylaştırılıp paylaştırılmadığı sorunu söz konusudur ${ }^{51}$. $\mathrm{Bu}$ konuda Alman hukukunda dava arkadaşları arasında yargılama giderlerinin paylaştırılmasına ilişkin ZPO § 100'ün ikinci fikrası örnek verilmektedir. Türk hukukunda benzer şekilde yargılama giderinin mahkemece paylaştırıldığı ve takdir edildiği Hukuk Muhakemeleri Kanunu'nun 326. maddesinin 3. fikrasi ${ }^{52}$ ve 331. maddenin 1. fikras $1^{53}$ düzenlemeleri mevcuttur. Bu durumlarda hâkimin, yargılama giderleri hakkında takdir hakkını doğru kullanmadığı gerekçesiyle hükmün tamamlanması yoluna başvurulamaz. Buna karşılık hâkim takdir hakkı da bulunsa yargılama giderleri hakkında hiç karar vermemişse, hükmün tamamlanmasının talep edilmesine bir engel yoktur.

Yargılama giderlerinin yanı sıra, kanun yolunun açık olup olmadığı ve başvuru süresi eksikse tamamlanması istenebilir. Kanun yolunun açık olup olmadığ unutulmuşsa, tamamlanması için hem hükmün gerekçesinde hem de hüküm fikrasında buna ilişkin bir ifadenin bulunmaması gerekir ${ }^{54}$. Bir başka deyişle hüküm fikrasında kanun yoluna ilişkin bir ifadenin yer almaması daima hükmün tamamlanmasını gerektirmez. Hükmün gerekçesinde kanun yolunun açık veya kapalı olduğu belirtilmiş fakat hüküm fikrasına alınmamışsa, burada eksiklik söz konusu olmayıp açık hata nedeniyle tashih edilmesi gerekir ${ }^{55}$.

\section{Tamamlama Talebi}

Hükmün tamamlanması, taraflardan birinin talebi üzerine mahkemece dikkate alınabilir. Hükümde eksiklik bulunsa da, mahkeme kendiliğinden hükmü tamamlayamaz ${ }^{56}$. Hükümde eksik kalan husus, yargılama gideri gibi mahkemece kendiliğinden dikkate alınması gereken bir husus olsa da re'sen tamamlama mümkün değildir ${ }^{57}$. Bu yönüyle hükmün tamamlanması, hükmün tashihinden ayrilmaktadır.

Tamamlama talebinde başvuracak tarafın, eksik kalan talebi yargılama sırasında ileri sürmüş olan taraf olması zorunlu değildir ${ }^{58}$. Hükmün tamamlanmasında hukukî menfaati olan tarafın bunu talep etmesi mümkündür.

\footnotetext{
49 “...Karar başlı̆̆ında davaya Aile Mahkemesi sıfatıyla bakıldı̆̆ ibaresinin eklenerek bu hususun açıkça belli edilmesi gerektiği halde gösterilmemiş ise de, davaya aile mahkemesi sıfatıyla bakıldı̆̆ına dair ara kararının varlı̆̆ ve yargılamanın bu sıfatla yürütüldüğünün anlaşılması karşısında, başlıktaki bu eksiklik mahkemesince düzeltilmesi her zaman için mümkün olan maddi hata niteliğindedir..." HGK, 8.12.2010, E. 2010/8-619, K. 2010/638 (GÖZÜTOK, Zeki/ALBAYRAK, Adem: Alfabetik Medeni Usul El Kitabı, Ankara, 2021, s.456).

${ }^{50}$ WIECZOREK/SCHÜTZE, §321, Kn. 15; MUSIELAK, §321, Kn. 7; BAUMBACH/LAUTERBACH, §321, Kn. 5.

${ }^{51}$ WIECZOREK/SCHÜTZE, §321, Kn. 14; MUSIELAK, §321, Kn. 7.

52 "Aleyhine hüküm verilenler birden fazla ise mahkeme yargllama giderlerini, bunlar arasında paylaştırabileceği gibi, müteselsilen sorumlu tutulmalarına da karar verebilir."

53 "Davanın konusuz kalmast sebebiyle davanın esası hakkında bir karar verilmesine gerek bulunmayan hâllerde, hâkim, davanın açıldı̆̆ tarihteki tarafların haklılık durumuna göre yargllama giderlerini takdir ve hükmeder.”

${ }^{54}$ WIECZOREK/SCHÜTZE, $\$ 321$, Kn. 19.

${ }^{55}$ WIECZOREK/SCHÜTZE, §321, Kn. 19; MUSIELAK, §321, Kn. 7a.

56 ROSENBERG/SCHWAB/GOTTWALD, \$61, Kn. 23; WIECZOREK/SCHÜTZE, $\quad \S 321, \quad$ Kn. 22; BAUMBACH/LAUTERBACH, §321, Kn. 6; TANRIVER, Süha: Medenî Usûl Hukuku, C. I, 3. Bası, Ankara, 2020, s.1042; GÖZÜTOK/ALBAYRAK, s.454.

${ }^{57}$ WIECZOREK/SCHÜTZE, §321, Kn. 22; STEIN/JONAS, §321, Kn. 19.

${ }^{58}$ STEIN/JONAS, §321, Kn. 19.
} 
Tamamlama talebinde bulunulmuş olması, asıl hükme karşı kanun yollarına başvurulmasını veya onun cebri icra yoluyla yerine getirilmesini engelleyici bir etki doğurmaz ${ }^{59}$. Tamamlama hükmü ile kanun yolları arasındaki ilişki ileride ayrıca incelenecektir ${ }^{60}$. Asıl hükme karşı ilâmlı icraya başvurulduktan sonra da hükmün tamamlanmasına başvurulabilir. Asıl hüküm icrası ile tamamlayıcı hükmün icrası arasındaki ilişki aşağıda ele alınacaktır ${ }^{61}$.

\section{Süre}

Hükmün tamamlanması, nihaî kararın tebliğinden itibaren bir ay içinde talep edilebilir. Süre, tarafların her birine tebliğinden itibaren başlar. Özellikle fer'i müdahil, fer'i müdahale gideri bakımından hükmün tamamlanması yoluna başvuracaksa, başvuru süresi, hükmün fer'i müdahile tebliğinden itibaren başlar ${ }^{62}$.

Alman hukukuna göre, taraflara kısa karar tebliğ edilmiş ise ve hükmün tamamlanmasının gerektiği bu kısa karardan anlaşılabiliyorsa, başvuru süresi bu kararın tebliğinden itibaren başlar ${ }^{63}$. Buna karşılık Türk hukuku bakımından, uygulamamızda kısa karar tebliğ edilmediği için böyle bir sonuca ulaşılamaz. Keza kısa kararda davanın kabul veya reddi kararı belirtmekle yetinildiğinden, HMK m.305/A'da sayılan hususlarda eksiklik olup olmadığı taraflarca kısa karardan tespit edilemez.

Hükmün tamamlanması süresinin kaçırılmış olması, maddi hukuk bakımından sonuç doğurmaz ${ }^{64}$. Süresi içerisinde hükmün tamamlanması talebine başvurulmamış veya süreye uyulmadığı için hükmün tamamlanması talebi reddedilmiş ise, hükümde eksik olan kısmın derdestliği artık sona erer. Unutulan talebin derdestliği sona erdiği için, bu talep yeni dava yoluyla ileri sürülebilir ${ }^{65}$. Bu husus özellikle eksik olan hüküm kesin olarak verilmiş veya istinaf kanun yoluna başvuru süresi dolmuş ise önem arz eder. Bu durumda Hukuk Muhakemeleri Kanunu'nun 353. maddesinin 1. fikrasının 6. bendi gereğince, kararda önemli bir eksiklik olduğu için kararın ilk derece mahkemesine geri gönderilmesi sebebine dayanılması ihtimali de ortadan kalkar. Dolayısıyla ilgili taraf hükmün tamamlanması süresini kaçırmışsa, yeni bir dava açma imkânına kavuşur. Ancak unutulan talep niteliği itibarıyla ayrı bir dava konusu yapılmaya elverişli değilse, örneğin yargılama gideri unutulmuş ise, ayrı bir dava konusu yapılamaz ${ }^{66}$. Bu açıklamalar, istinaf aşamasında da geçerlidir. Bir başka deyişle, istinaf mahkemesinin verdiği kararda eksiklik bulunması halinde, hükmün tamamlanmasına başvuru süresi dolmuş ve eksik karara karşı temyiz yolu kapalı veya temyiz süresi kaçırılmış ise, söz konusu unutulan talebin derdestliği sona erecektir.

Hükmün tamamlanmasına ilişkin Hukuk Muhakemeleri Kanunu'nda hüküm bulunmadığ1 dönemde, talep edilen faiz hakkında karar verilmediği takdirde, Yargıtay eski tarihli içtihatlarında, talebin zımnen reddedildiğini, bu nedenle kesin hüküm ortaya çıktığı için faizin daha sonra dava edilemeyeceğini belirtmişti ${ }^{67}$. Daha sonra Yargıtay bu içtihadının tersine ve daha doğru bir yorumla faiz hakkında karar verilmediği takdirde ortada bir hüküm bulunmadığını ve faizin yeni bir dava yoluyla talep edilebileceğini belirtmekteydi ${ }^{68}$. Hüküm verirken unutulan faiz talebi hakkında tavzih

\footnotetext{
59 TANRIVER, s.1043.

${ }^{60} \mathrm{Bkz}$. VI.

${ }^{61} \mathrm{Bkz} . \mathrm{V}, \mathrm{B}$.

${ }^{62}$ WIECZOREK/SCHÜTZE, $§ 321$, Kn. 15, 29; MUSIELAK, §321, Kn. 9; THOMAS/PUTZO, §321, Kn. 2; STEIN/JONAS, $\S 321, \mathrm{Kn} .20$; BAUMBACH/LAUTERBACH, §321, Kn. 7.

63 PRÜTTING/GEHRLEIN, §321，Kn. 7; WIECZOREK/SCHÜTZE，§321，Kn. 27; MUSIELAK， 3321，Kn. 9; STEIN/JONAS, $\$ 321$, Kn. 20.

${ }^{64}$ PRÜTTING/GEHRLEIN, $\$ 321$, Kn. 7.

${ }^{65}$ ROSENBERG/SCHWAB/GOTTWALD, §61, Kn. 28; THOMAS/PUTZO, § 321, Kn. 3; PRÜTTING/GEHRLEIN, §321, Kn. 7; STEIN/JONAS, §321, Kn. 20; WIECZOREK/SCHÜTZE, §321， Kn. 30; MUSIELAK, §321, Kn. 9;
} BAUMBACH/LAUTERBACH, §321, Kn. 6; FASCHING, §423, Kn. 12.

Alman hukukunda ZPO §533 veya §264, II hükümlerine göre istinaf aşamasında da iddianın genişletilmesi mümkün olduğundan, buna dayanılarak yeni talebin istinaf aşamasında ileri sürülmesi kabul edilmektedir (ROSENBERG/SCHWAB/GOTTWALD, §61, Kn. 28; THOMAS/PUTZO, §321, Kn. 3; STEIN/JONAS, §321, Kn. 24; BAUMBACH/LAUTERBACH, $\$ 321$, Kn. 4).

${ }^{66}$ PRÜTTING/GEHRLEIN, §321, Kn. 7; WIECZOREK/SCHÜTZE, §321, Kn. 30; FASCHING, §423, Kn. 12.

67 “...Önceki davanın müddeabihine dâhil faiz hakkında o zaman bir karar verilmemiş olması o isteğin reddedilmiş olduğu anlamına gelmektedir. Bir davada açıç̧a ve zımnen reddedilmiş bir husus ayrı bir dava konusu olamaz. Kesin hüküm ikinci davanın dinlenmesine engeldir...” HGK, 16.12.1967, E. T/139, K. 618 (ÜSTÜNDAĞ, Saim: Medeni Yargılama Hukukunun Esaslar1, 7. Bas1, İstanbul, 2000, s.807-808).

${ }^{68}$ HGK, 4.5.1968, E. 1966/5, K. 1968/296 (ÜSTÜNDAĞ, s. 808-809); “...Olayda, davacı tarafindan evvelce açılan davada faiz istenilmiş ancak bu konuda mahkemece olumlu veya olumsuz hiçbir karar verilmemiştir. O halde faiz istemi hakkında, ...kesin hükmün varlığından söz edilemez. Diğer taraftan önceki dava sonunda verilen kararı davacının temyiz etmemiş olması faiz isteminden vazgeçmiş olduğu anlamına da gelmez...” HGK, 17.11.1973, E. 1971/762, K. 1973/901 (Lexpera); “...Davacı, istemlerinden biri hakkında karar verilmemiş olması nedeniyle temyiz yoluna başvurmazsa, hakkında olumlu veya olumsuz bir karar verilmemiş olan bu talep zımnen reddedilmiş sayılamaz. Bu konuda yeni bir dava açılabilir..." 3. HD, 
yolu ile de karar verilmesi mümkün değildir ${ }^{69}$. Artık hükmün tamamlanmasına ilişkin Hukuk Muhakemeleri Kanunu'nun 305/A maddesinin kabul edilmesi ile mahkemece karar verilmesi unutulan faiz hakkında ek bir karar verilmesi mümkün hale gelmiştir.

\section{HÜKMÜN TAMAMLANMASININ USÛLÜ}

Hükmün tamamlanması talebinin nasıl yapılacağı ve yargılama usûlü Hukuk Muhakemeleri Kanunu'nun 306. maddesinde düzenlenmiştir. Hükmün tamamlanmasına ilişkin usûlün, tavzihin yapılma usûlü ile beraber düzenlenmiş olması doktrinde eleştirilmektedir ${ }^{70}$. Söz konusu görüşe göre, hükmün tamamlanmasına ilişkin usûl ya tavzihten ayrı olarak ya da tavzihle beraber düzenlenecekse de farklı yönleri ortaya konularak düzenlenmeliydi.

Hükmün tamamlanmasının isteneceği görevli ve yetkili mahkeme eksik hükmü veren mahkemedir. Bu yola dilekçe ile başvurulur. Tamamlama talebi dilekçesine tarafların sayısı kadar nüsha eklenir. Dilekçenin bir nüshası talebin karşı tarafına tebliğ edilir. Karşı tarafın tamamlama talebine cevap verme hakkı vardır. Burada cevap süresi, mahkeme tarafından takdir edilir. Karşı tarafın tamamlama talebine karşı verdiği cevap dilekçesi tamamlama talebinde bulunana tebliğ edilir. Artık burada ikinci dilekçelerin verilmesi söz konusu değildir.

Tamamlama talebinin mahkeme tarafindan incelenmesi kural olarak dosya üzerinden yapılır. Tamamlama talebine karşı tarafın cevap verip vermediğine bakılmaksızın dosya üzerinden inceleme yapılması mümkündür. Fakat mahkeme gerekli görürse, iki tarafı sözlü açıklamalarda bulunmak üzere duruşmaya davet edebilir. Taraflara sözlü açıklamada bulunma hakkının, özellikle mahkemece unutulan talebin uyuşmazlığın esasına ilişkin olması halinde verilmesi gerekir. Buna karşılık unutulan talep, uyuşmazlığın esasına ilişkin olmayıp örneğin yargılama gideri gibi bir husus hakkında ise tamamlama talebi dosya üzerinden incelenmelidir ${ }^{71}$. Keza Alman hukukunda yargılama giderleri ve tali taleplere ilişkin dosya üzerinden karar verilmesi mümkün iken asli talep bakımından sözlü yargılamanın yapılması esastır (ZPO § 321, III). Avusturya hukukunda da yalnızca yargılama giderleri bakımından dosya üzerinden karar vermek mümkün iken diğer hususlar bakımından mahkeme gerekli görürse sözlü yargilama yapar (öZPO § 423, III) ${ }^{72}$.

Hükmün tamamlanması talebi hakkında duruşmalı inceleme yapılmasına karar verilmiş ise tarafların birinin veya her ikisinin duruşmaya gelmemesi halinde Hukuk Muhakemeleri Kanunu'nun 150. maddesinin hükümleri uygulanabilir mi? Kanaatimizce hükmün tamamlanması hakkında duruşma yapılması, hükümde eksik kalan husus hakkında yeniden tahkikat yapılması anlamına gelmez. Bu duruşmada mahkeme, yalnızca tarafları dinlemekle yetinir. Bu nedenle hükmün tamamlanması duruşmasına taraflardan biri veya her ikisi gelmez ise, tarafların geçerli bir mazereti bulunmasa dahi, mahkemenin dosya üzerinden karar vermesi gerekir (HMK 306. maddesinin 3. fikrasinda, tavzihi düzenleyen HMK 304. maddeye yapılan atıf gereğince).

Mahkeme tamamlama talebinin kabulüne karar verirse, Hukuk Muhakemeleri Kanunu'nun 304. maddesine göre işlem yapar. Buna göre, tamamlanan hususlara ilişkin ek karar, mahkemede bulunan nüshalar ile verilmiş olan suretlerin altına veya bunlara eklenecek ayrı bir kâğıda yazılarak imzalanır ve mühürlenir. Tamamlama talebinin reddi de ek karar olduğundan, asıl hükmün altına veya ayrı bir kâğıda ret kararının yazılması gerekir.

\section{TAMAMLAMA TALEBİ ÜZERİNE VERÍLEN KARARLAR}

\section{A. Genel Olarak}

Mahkeme, Hukuk Muhakemeleri Kanunu'nun 305/A maddesindeki şartlarla hükümde eksik bırakılmış bir husus olduğunu tespit ederse, tamamlama talebinin kabulüne karar verir. Hükmün tamamlanması talebinin mahkemece kabul edilmesi üzerine "tamamlayıcı hüküm" verilir" Tamamlama talebi, gerekli şartlara sahip değilse, mahkeme tamamlama talebinin reddine karar verir. Gerek tamamlama talebinin kabulü (tamamlayıcı hüküm) gerek tamamlama talebinin reddi kararları ek karar niteliğindedir. Çünkü her iki karar da mahkemenin nihaî karar vermesinden bir başka deyişle hâkimin dosyadan el çekmesinden sonra verilir. Tamamlama talebi üzerine verilen karar, taraflara tebliğ edilir.

29.04.2010, E. 2010/3736, K. 2010/7646 (Lexpera); ayn1 yönde 22. HD, 13.10.2015, E. 2015/24904, K. 2015/28475 (Lexpera).

${ }^{69}$ ARSLAN, Ramazan/YILMAZ, Ejder/TAŞPINAR AYVAZ, Sema/HANAĞASI, Emel: Medenî Usûl Hukuku, 6. Bas1, Ankara, 2020, s.723.

${ }^{70}$ PEKCANITEZ/ATALAY/ÖZEKES, 7251 sayılı Kanun, s.280.

${ }^{71}$ ARSLAN/YILMAZ/TAŞPINAR AYVAZ/HANAĞASI, s.724.

${ }^{72}$ RECHBERGER/KLICKA, §423, Kn. 4.

${ }^{73}$ TANRIVER, s.1043. 
Tamamlayıcı hüküm, ek karar niteliğinde olmakla beraber, hukukumuzda ek kararın tek görünüm biçimi değildir. Mahkemenin nihaî kararını vermesinden sonra, dava dosyası ile ilgili bir karar vermesi gereken başka hallerde de ek karar verilebilir. Örneğin, istinaf dilekçesi ilk derece mahkemesi tarafindan (HMK m.346) ek karar ile reddedilir veya davadan feragat veya davayı kabul hükmün verilmesinden sonra yapılmışsa taraflarca kanun yoluna başvurulmuş olsa dahi, ilk derece mahkemesi veya bölge adliye mahkemesince feragat veya kabul doğrultusunda ek karar verilir (HMK m.310/II).

Tamamlama talebi üzerine verilen kabul veya ret kararı, asıl hükmün altına veya buna eklenecek ayrı bir kâğı̆da yazılacağından, bu karar, bir başka esas numarası verilmeksizin asıl hükmün esas numarası altında verilir ${ }^{74}$. Bu husus önemini özellikle kanun yolu bakımından göstermektedir. Hem asıl hükme hem de tamamlama talebi üzerine verilen karara karşı kanun yollarına başvurulduğunda aynı esas numarası üzerinden işlem yapılarak zamansal olarak her iki kararın incelenmesi de beraber yapilabilecektir ${ }^{75}$.

\section{B. Tamamlayıcı Hükmün Hukukî Niteliği}

Alman ve Avusturya hukuklarına göre, tamamlayıcı hüküm asıl hükümden bağımsız bir hükümdür ve asıl hüküm karşısında kısmî hüküm (Teilurteil) niteliğindedir ${ }^{76}$. Tamamlayıcı hüküm içerik itibarıyla başlı başına bir hüküm gibi verilir ve bir hükmün tüm unsurlarını içeriri ${ }^{77}$.

Türk hukukunda bir görüşe göre, tamamlayıcı hüküm kısmî hüküm niteliğindedir ${ }^{78}$. Kısmî hüküm, doktrinde, "bölünebilen ve bağımsız olarak bir hükme konu olacak şekilde sinırlanabilen dava konusunun, karar verme olgunluğuna ulaşmış bir kısmı hakkında yargılamayı nihâ̂ olarak sona erdiren kararlar" olarak tanımlanı ${ }^{79}$. Kısmî hüküm ile davacının talep sonucunun bir kısmı sonuçlandırılı8 ${ }^{80}$. Kısmî hüküm, hükmün geri kalan kısmı karşısında ayrı olarak kanun yollarına götürülebilir, icra edilebilir ve kesin hüküm halini alır ${ }^{81}$.

Kanaatimizce tamamlayıcı hüküm, asıl hüküm karşısında kısmî bir hüküm niteliğinde olmakla beraber, Alman veya Avusturya hukuklarındaki gibi ondan bağımsız bir hüküm olduğunu söylemek güçtür. Çünkü gerek Hukuk Muhakemeleri Kanunu'nun 306. maddesinde tamamlama usûlünün tavzih usûlü ile beraber düzenlenmesi gerekse Hukuk Muhakemeleri Kanunu'nun 304. maddesine yapılan atıf karşısında, tamamlayıcı hüküm asıl hükümden bağımsızlaşan bir karar niteliğinde değildir. Tamamlama talebi üzerine verilen ek karar, asıl hükmün ayrılmaz bir parçası niteliğinde kabul edilmelidir $^{82}$. Bu tespit, özellikle tamamlayıcı hükme karşı kanun yollarına başvuru şartları bakımından önem arz etmektedir ki bu husus ileride incelenecektir. Ayrıca tamamlayıcı hükmün asıl hükmün bir parçası olarak kabul edilmesinin başka bir sonucu, tamamlayıcı hükmün ilâmlı icra konusu yapılmasında görülür. Bu durumda tamamlayıcı hüküm, edaya ilişkin bir hüküm içeriyorsa, bu hükmün asıl hükme karşı başlatılan icra takibi dosyası içerisinde yerine getirilmesi talep edilebilir. Başka bir deyişle tamamlayıcı hüküm, asıl hükümden ayrı olarak ilâmlı icraya konu edilemez.

Hukukumuzda tahkim yargılaması bakımından, tamamlayıcı hakem kararının, önceki hakem kararının bir parçası niteliğinde olduğu açıķ̧a düzenlenmiştir (HMK m.437, V). Hükmün tamamlanması konusunda da böyle bir düzenlemenin yer alması isabetli olacaktır ${ }^{83}$. Böylece uygulamada özellikle kanun yolları ve ilâmlı icra bakımından ortaya çıkacak tereddütlerin bu yöndeki bir düzenleme sayesinde giderilmesi mümkün hale gelecektir.

\section{ASIL HÜKME KARŞI GIDILEN KANUN YOLLARI ILE HÜKMÜN TAMAMLANMASI ARASINDAKİ İLIŞKİ}

İlk derece mahkemesi kararının taraflara tebliğinden itibaren hem istinaf kanun yoluna başvuru süresi hem de hükmün tamamlanmasına başvuru süresi başlar. Eksik bir hükme karşı hükmün tamamlanması yoluna başvurulması, asıl hükme karşı kanun yollarına başvurulmasını engellemez.

\footnotetext{
${ }^{74}$ ARSLAN/YILMAZ/TAȘPINAR AYVAZ/HANAĞASI, s.724.

75 ÖZTEK, Selçuk/TAŞPINAR AYVAZ, Sema/KALE, Serdar: "Hukuk Muhakemeleri Kanunu ile Bazı Kanunlarda Değişiklik Yapılması Hakkında 20 Mart 2020 tarihli Kanun Teklifi'ne İlişsin Bazı Açıklamalar ve Kanun Teklifinin Değerlendirilmesi”, TBBD, 149, 2020, s.137.

${ }^{76}$ ROSENBERG/SCHWAB/GOTTWALD, §61, Kn. 26; PRÜTTING/GEHRLEIN, §321, Kn. 9; WIECZOREK/SCHÜTZE, §321, Kn. 34, 37; MUSIELAK, §321, Kn. 12; THOMAS/PUTZO, §321, Kn. 6; BAUMBACH/LAUTERBACH, §321, Kn. 10; FASCHING, $\$ 423, \mathrm{Kn} .16$.

77 WIECZOREK/SCHÜTZE, §321, Kn. 34; MUSIELAK, §321, Kn. 12.

${ }^{78}$ PEKCANITEZ/ATALAY/ÖZEKES, Usûl, s.436.

${ }^{79}$ BAHADIR, s.22.

${ }^{80}$ PEKCANITEZ/ATALAY/ÖZEKES, Usûl, s.428.

${ }^{81}$ PEKCANITEZ/ATALAY/ÖZEKES, Usûl, s.429; BAHADIR, s.23.

82 ÖZTEK/TAȘPINAR AYVAZ/KALE, s.137; ARSLAN/YILMAZ/TAŞPINAR AYVAZ/HANAĞASI, s.724.

${ }^{83}$ PEKCANITEZ/ATALAY/ÖZEKES, 7251 sayılı Kanun, s.283.
} 
Aynı şekilde, asıl hükme karşı kanun yollarına başvurulmasından sonra hükmün tamamlanmasına başvurulması da mümkündür. Bu yollardan birine başvuru bakımından ilgili tarafin seçim hakkı bulunur $^{84}$. Bununla beraber burada dikkat edilmesi gereken birkaç husus vardır. Hükümde eksik bırakılan husus, aynı zamanda istinaf sebebi yapılabilir mi, yapılabilirse hem istinaf hem de hükmün tamamlanması yoluna başvurulmuşsa nasıl karar verilmelidir sorularının cevaplanması gerekir.

Hukukumuzda hükmün tamamlanması yolu kabul edilmeden önce, hükümde eksik bırakılmış bir husus var ise, bunun istinaf sebebi yapılmasında herhangi bir tereddüt yaşanmazd ${ }^{85}$. Bu durumda istinaf mahkemesi, talebin önemli bir kısmı hakkında karar verilmemiş olması nedeniyle dosyanın ilk derece mahkemesine geri gönderilmesine (HMK m.353, I, a, 6) karar verebilir. Eksik kalan husus, talebin önemli bir kısmı olmayıp örneğin vekâlet ücretinin unutulması gibi bir husus ise istinaf mahkemesi de yeniden bir karar verebilir (HMK m.353, II-III).

Hükmün tamamlanmasının kabul edilmesinden sonra, eksik kalan kısmın tamamlanmasında menfaati bulunan tarafin bunu istinaf kanun yoluna götürmeyerek yalnızca hükmün tamamlanması yoluna başvurmasında herhangi bir engel veya sakınca bulunmamaktadır. Hatta davanın tarafları bakımından başvurabilecekleri hukukî çare imkânlarının genişlemesi nedeniyle etkin hukukî himayeye hizmet eden bir sonuca da ulaşılmaktadır. Özellikle istinaf kanun yolunun kapalı olduğu veya başvuru süresinin kaçırıldığı hallerde dahi Hukuk Muhakemeleri Kanunu'nun 305/A maddesi uygulanabileceğinden eksik olan hükümlerin tamamlanmasının kanun değişikliği ile mümkün hale gelmesi tarafların menfaatinedir. Ayrıca hükümdeki tek sorun eksikliğin giderilmesi ise, yalnızca hükmün tamamlanmasının talep edilmesi sayesinde kanun yolları da meşgul edilmemiş olur.

Taraflardan biri, hükümde bulunan eksiklik için hem istinaf kanun yoluna başvurmuş hem de hükmün tamamlanmasını talep etmiş ise, Avusturya Medenî Usûl Kanunu § 485'te özel bir düzenleme bulunmaktadır. Buna göre, tamamlama talebi hakkında karar verilene kadar istinaf yargılaması talep üzerine ertelenir. Tamamlama talebi hakkında kesinleşmiş bir karar verilir ve hüküm tamamlanırsa, hükmün eksik olduğuna dayanan istinaf sebebi ortadan kalktığı için istinaf başvurusu artık geri çevrilir ${ }^{86}$. Türk hukukunda böyle açık bir kanunî düzenleme bulunmamaktadır. Fakat hukukumuzda da ilk derece mahkemesi aşamasında hükümdeki eksikliğin giderilmesi ihtimali karşısında istinaf incelemesinin, hükmün tamamlanması hakkında bir karar verilene kadar ertelenmesi uygun düşer. $\mathrm{Bu}$ konuda Hukuk Muhakemeleri Kanunu'nun 360. maddesi gereğince istinaf aşamasında ilk derece mahkemelerindeki yargılama usûlünün uygulanması imkânına dayanılarak istinaf yargılamasının bekletilmesi kanaatimizce mümkündür ${ }^{87}$. Aksi durumda birbiri ile çelişen kararların ortaya çıkma ihtimali söz konusu olabilir.

Hükmün tamamlanması talebi üzerine verilen kabul veya ret kararının taraflara tebliğ edilmesinin asıl karara karşı istinaf başvuru süresine etkisi hakkında mukayeseli hukuk bakımından birbirine zıt yönde iki kanunî düzenleme bulunmaktadır. Alman hukukuna göre, istinafa başvuru süresi içerisinde hükmün tamamlanmasına yönelik bir ek karar verilmiş ise, bu ek kararın tebliğinden itibaren asıl karara karşı istinafa başvuru süresi yeniden işlemeye başlar (ZPO § 518, 1. cümle). Söz konusu madde, temyiz kanun yolu bakımından da uygulanır (ZPO § 555) ${ }^{88}$. Bu kural sayesinde, her iki karara karşı birlikte kanun yoluna başvurulması ve incelemenin birlikte yapılarak karar verilmesi sağlanır ${ }^{89}$. Her iki karara karşı aynı taraf istinaf kanun yoluna başvurmuş ise, yapılan inceleme birbirini bağlar (ZPO § 518, 2. cümle). Fakat taraflardan biri sadece tamamlayıcı hükmü kanun yoluna götürmüş ise, tamamlayıcı hükmün bağımsılığı nedeniyle, kanun yolu mahkemesi yalnızca tamamlayıcı hüküm hakkında bir karar verebilirr ${ }^{90}$. Bunun yanı sıra yargı içtihatlarında, yargılama giderleri hakkındaki tamamlayıcı hükmün kısmî karar değil, son karar olarak ele alınması ve ilk verilen kararı istinaf etmekle yargılama giderine ilişkin tamamlama hükmüne karşı da kanun yoluna gidilebileceği kabul edilmektedir ${ }^{91}$. Z1t yöndeki diğer düzenleme ise Avusturya hukukunda öZPO § 424'e aittir. Buna göre,

\footnotetext{
${ }^{84}$ RECHBERGER/KLICKA, §423, Kn. 3. Buna karşılık Avusturya hukukunda azınlıkta kalan bir görüşe göre, hükmün tamamlanması ile kanun yoluna başvuru arasında tarafların seçim hakkı bulunmaz; hükmün tamamlanmasına sehven unutulan hususlar için başvurulabilirken istinaf yoluna mahkemece bilerek karar verilmeyen hususlar için başvurulabilir (Bkz. RECHBERGER/KLICKA, §423, Kn. 3’teki yazarlar).

${ }^{85}$ Hukuk Muhakemeleri Kanunu ile Bazı Kanunlarda Değișiklik Yapılması Hakkında Kanun Teklifi (2/2735) ve Adalet Komisyonu Raporu, s.17; BUDAK/KARAASLAN, 7251 Sayılı Kanun, s.25; BUDAK/KARAASLAN, Usûl, s.307.

${ }^{86}$ FASCHING, $\$ 423$, Kn. 2; RECHBERGER/KLICKA, §423, Kn. 3.

${ }^{87}$ Doktrinde ileri sürülen aksi yöndeki bir görüşe göre, ek karar istinaf mahkemesi için bekletici sorun oluşturmamalıdır (PEKCANITEZ/ATALAY/ÖZEKES, 7251 sayılı Kanun, s.282).

${ }^{88}$ ROSENBERG/SCHWAB/GOTTWALD, §61, Kn. 27; WIECZOREK/SCHÜTZE, §321, Kn. 39.

${ }^{89}$ ROSENBERG/SCHWAB/GOTTWALD, §61, Kn. 27.

${ }^{90}$ PRÜTTING/GEHRLEIN, 3321, Kn. 9.

${ }^{91}$ STEIN/JONAS, §321, Kn. 38.
} 
hükmün tamamlanmasına ilişkin yargılamanın, kanun yoluna başvuru süresine herhangi bir etkisinin olmadığı düzenlenmiştir.

Türk hukukunda hükmün tamamlanmasının istinaf kanun yoluna başvuru süresi ile ilişkisi bakımından hiçbir kanunî düzenleme yer almamaktadır. Bu yönde bir kanunî düzenleme bulunmaması karşısında, Alman hukukundaki gibi, hükmün tamamlanması talebine ilişkin kararın tebliğ edilmesi ile asıl hükme karşı istinafa başvuru süresinin yeniden işlemeye başlaması mümkün değildir. Alman hukukunda istinafa başvuru süresi ve hükmün tamamlanmasına başvuru süresi aynı olduğundan, tamamlama talebi üzerine verilen karardan sonra asıl karara karşı istinaf süresinin uzaması anlamlıdır. Ancak bizim hukukumuzda hükmün tamamlamasına başvuru süresi istinaf süresinden uzun olduğu için, bir de tamamlama talebi üzerine verilen karardan sonra asıl karara karşı tekrar istinafa başvuru süresi tanınması süreci çok fazla uzatacaktır. Ayrıca tarafların soyut sebeplerle hükmün tamamlanması yoluna başvurarak bu yolu kötüye kullanma ihtimali de ortaya çıkabilir. Bu nedenle Türk hukukunda hükmün tamamlanması kabul edilirken ZPO § 518, I gibi bir düzenlemenin yer almaması isabetli olmuştur.

\section{TAMAMLAYICI HÜKME KARȘI KANUN YOLLARI}

Hukuk Muhakemeleri Kanunu'nun 305/A maddesinin 1. fikrasının 2. cümlesine göre, tamamlama talebi üzerine verilen kararlara karşı kanun yolları açıktır. Buna göre yalnızca tamamlayıcı hüküm değil, tamamlama talebinin reddi kararlarına karşı da kanun yollarına başvurulması mümkündür ${ }^{92}$.

Tamamlayıcı hüküm bakımından kanun yollarına başvuru şartları belirlenirken bu şartların sadece ek karar için mi aranacağının, yoksa asıl kararın kanun yollarına açık olup olmadığına göre mi tespit edileceğinin belirlenmesi gerekir. Bu soruya verilecek yanıt, tamamlayıcı hükmün asıl hüküm ile arasındaki ilişkinin hukukî niteliğine göre değişir. Çünkü tamamlayıcı hüküm, asıl hükümden bağımsız bir karar olarak kabul edilirse, kanun yollarına başvuru şartları bakımından da asıl hükümden bağımsız olduğu sonucuna varmak gerekir. Alman ve Avusturya hukuklarında bu anlayış benimsenmiştir. Bu hukuk sistemlerinde tamamlayıcı hükmün kanun yollarına başvuru şartları asıl hükümden bağımsız olarak değerlendirilir ${ }^{93}$.

Kanaatimizce Türk hukukunda tamamlama talebi üzerine verilen kararları asıl hükümden tamamen bağımsız olarak değerlendirmek mümkün olmadığından, kanun yollarına başvuru şartları için de asıl hükme göre bir değerlendirme yapılmalıdır. Bu husus, özellikle malvarlığına ilişkin davalarda parasal sınırın tespiti bakımından önem arz eder. Asıl hüküm, kanun yollarına kapalı bir karar ise, bu karara ek olarak verilen tamamlayıcı hükme karşı da kanun yolu kapalı olur ${ }^{94}$. Tam tersi, asıl hükme karşı kanun yollarına başvurulabiliyorsa tamamlayıcı hükme karşı da kanun yoluna gidilebilir. Parasal sınır bakımından şu tespitler yapılmalıdır: Asıl hüküm bakımından kanun yolu açık olup da bu karar parasal sınırın üzerinde kalıyor ve tamamlayıcı hükümdeki miktar da tek başına parasal sınırın üzerinde ise bir sorun yoktur. Fakat tamamlayıcı hükümdeki miktar tek başına kanun yoluna başvuruda parasal sınırın altında kalıyorsa ne olacağı belirlenmelidir. Kanaatimizce tamamlayıcı hüküm istinaf kanun yoluna götürülürken parasal sınırın hesaplanmasında, asıl hüküm ile tamamlayıcı hükümdeki dava konusunun miktar veya değerinin toplamı dikkate alınmalıdır ${ }^{95}$. Bir başka deyişle, mahkeme asıl hükümde tarafların ileri sürdügü talebin tamamı veya bir kısmını unutmamış olsa ve buna göre mahkeme kararı parasal sınırın üstünde kalacak olsa idi, tamamlayıcı hükümdeki miktar tek başına parasal sınırın altında kalsa bile, toplam miktar parasal sınırın üzerinde ise kanun yolunun açık olduğu kabul edilmelidir. Hükmün tamamlanmasının konusu manevi tazminat ise, bu durumda parasal sınır şartı aranmaksızın kanun yollarına başvurulabilir (HMK m.341, II, cümle 2). Bu noktada tamamlayıcı hükmün yargılama giderleri gibi hükmün fer'i nitelikteki sonuçları hakkında verilmiş olması halinde de asıl hükme karşı kanun yolu açık ise tamamlayıcı hükme karşı kanun yollarına gidilmesi mümkün olmalıdır. Kanun yoluna başvuru bakımından, hakkında eksik hüküm verilen davanın türünün de göz önünde tutulması gerekir. Objektif dava birleşmesi biçiminde açılmış birden fazla talepten biri hakkında karar verilmesi unutulmuş ise, parasal sınır her bir talep bakımından ayrı ayrı dikkate alınmalidır ${ }^{96}$.

\footnotetext{
92 PEKCANITEZ/ATALAY/ÖZEKES, 7251 sayılı Kanun, s.283.

${ }^{93}$ ROSENBERG/SCHWAB/GOTTWALD, §61, Kn. 26; MUSIELAK, §321, Kn. 13; THOMAS/PUTZO, §321, Kn.6; PRÜTTING/GEHRLEIN, $\$ 321, \quad \mathrm{Kn} . \quad 9 ; \quad$ STEIN/JONAS， $\$ 321 ， \quad$ Kn. $\quad 35 ; \quad$ FASCHING, $\$ 423, \quad \mathrm{Kn} . \quad 16$; RECHBERGER/KLICKA, §423, Kn. 5.

${ }^{94}$ PEKCANITEZ/ATALAY/ÖZEKES, 7251 sayl1 Kanun, s.283; GÖZÜTOK/ALBAYRAK, s.454.

${ }^{95}$ GÖZÜTOK/ALBAYRAK, s.454.

${ }^{96}$ PEKCANITEZ/ATALAY/ÖZEKES, Usûl, s.477.
} 


\section{HUKUK MUHAKEMELERI KANUNU'NUN 305/A MADDESINIIN ZAMAN BAKIMINDAN UYGULANMASI}

Hükmün tamamlanmasına ilişkin kurallar bakımından kanun koyucu herhangi bir geçiş (intikâl) hükmü öngörmemiştir. Bu nedenle bu kuralların zaman bakımından uygulanmasında genel kuralın dikkate alınması gerekirr ${ }^{97}$. Usûl kuralları tamamlanmış işlemleri etkilememek kaydıyla derhal uygulanır (HMK m.448). Bunun anlamı, tamamlanmış işlemler geçerliliğini muhafaza ederken tamamlanmamış işlemlerin yeni yürürlüğe giren usûl kurallarına tâbi olmasıdır (derhâl uygulanırlık ilkesi $)^{98}$.

Hükmün tamamlanmasına ilişkin kanun değiş̧ikliği 28.7.2020 tarihinde yürürlüğe girmiştir. Dolayısıyla bu tarihte henüz tamamlanmamış olan usûl işlemlerine hükmün tamamlanması kuralları uygulanır. Buna göre, bu tarihten sonra açılmış olan davalarda verilen hükümler bakımından hükmün tamamlanmasının istenebileceğine kuşku yoktur.

28.7.2020 tarihinden önce açılmış olan davalar bakımından ise bazı tespitlerin yapılması gerekir. 28.7.2020 tarihinden önce açılmış olan davalarda, hüküm bu tarihten sonra verilmiş ve hükümde Hukuk Muhakemeleri Kanunu'nun 305/A maddesi anlamında eksiklik var ise, taraflar hükmün tamamlanmasını talep edebilirler. Bu noktada, hüküm söz konusu tarihten önce verilmiş ise Hukuk Muhakemeleri Kanunu'nun 305/A maddesinin uygulanma kabiliyeti var midır sorusu sorulmalidır. Kanaatimizce bu durumda hükmün tebliğ edildiği tarihe bakılmalıdır. Hüküm 28.7.2020'den önce verilmiş ve fakat bu tarihten sonra taraflara tebliğ edilmiş ise, hükmün tamamlanmasının talep edilmesi mümkündür. Bununla beraber, hüküm hem 28.7.2020'den önce verilmiş hem de bu tarihten önce tebliğ edilmiş ise, hükmün tamamlanması yoluna ancak bir aylık süre dolmamış ise başvurulabilir. Bir başka deyişle 28.7.2020'den önce hüküm verilmiş, taraflara tebliğ edilmiş ve başvuru süresi de bu tarihten önce dolmuşsa artık hükmün tamamlanması yoluna başvuru imkânı kalmaz.

\section{SONUÇ}

Hukuk Muhakemeleri Kanunu'na 7251 sayılı Kanun ile eklenen 305/A maddesi, medenî usûl hukukumuza "hükmün tamamlanması" kurumunu kazandırmıştır. Hükmün tamamlanmasına ilişkin getirilen yeni düzenleme ile beraber, mahkemenin nihaî karar verirken karar vermeyi unuttuğu hususlar bakımından hükmün tamamlanması imkânı kabul edilmiştir.

Hükmün tamamlanması kanun yolu değildir; hukukî niteliği itibarıyla hukukî çare niteliğindedir. Çünkü hükmün tamamlanması, kanun yollarının genel özellikleri olan aktarıcı ve erteleyici etkiye sahip değildir.

Hükmün tamamlanması yoluna başvurulması için, öncelikle nihaî bir mahkeme kararının bulunması gerekir. Hukuk Muhakemeleri Kanunu'nun 305/A maddesinde yalnızca "hüküm" ifadesi yer alsa da mahkeme tarafından verilen tüm nihaî kararlar bakımından söz konusu kuralın uygulanması mümkündür. Hükmün tamamlanmasına başvurulacak nihaî kararın türü önem arz etmez. Dolayısıyla esasa ilişkin nihaî kararlar, usûle ilişkin nihaî kararlar veya karar verilmesine yer olmadığı kararları için hükmün tamamlanması talep edilebilir. Hatta tamamlayıcı hükmün kendisi de şartları varsa tamamlanabilir.

Hukuk Muhakemeleri Kanunu'nun 305/A maddesi anlamında hakkında kısmen veya tamamen karar verilmemiş olan "husus"lar, "yargılamada ileri sürülen" ve "kendiliğinden hükme geçirilen" hususlar olarak ikiye ayrılır. Bu iki grup "husus"u birbirinden ayıran özellik, ilkinin taraflarca ileri sürülmesi, ikincisinin mahkemece re'sen hükme geçirilmesidir. "Yargılamada ileri sürülen husus" ifadesinden medenî usûl hukuku bakımından anlaşılması gereken "talep" kavramıdır.

Hukuk Muhakemeleri Kanunu'nun 306. maddesinde tamamlama usûlünün tavzih usûlü ile beraber düzenlenmesi ve 304. maddeye yapılan atıf karşısında, tamamlama hükmü asıl hükümden bağımsızlaşan bir karar niteliğinde değildir. Tamamlama talebi üzerine verilen ek karar, asıl hükmün ayrılmaz bir parçası niteliğinde kabul edilmelidir. Bu tespit özellikle tamamlayıcı hükme karşı kanun yollarına başvuru şartları bakımından önem arz eder.

Hukuk Muhakemeleri Kanunu'nun 305/A maddesinin olmadığı dönemde, eksik kalan hususlar yalnızca şartları varsa kanun yollarında ileri sürülebilmekteydi. Ancak kanun yoluna kapalı bir karar bakımından bu imkân da bulunmamaktaydı. Hükmün tamamlanması sayesinde, eksik kalan nihaî

\footnotetext{
97 ARSLAN/YILMAZ/TAŞPINAR AYVAZ/HANAĞASI, s.65; PEKCANITEZ/ATALAY/ÖZEKES, Usûl, s.17; PEKCANITEZ, Hakan: Pekcanıtez Usûl-Medeni Usûl Hukuku, C. I, İstanbul, 2017, s.43; ATALI/ERMENEK/ERDOĞAN, s.25; TANRIVER, s.132.

${ }^{98}$ TAŞPINAR AYVAZ, Sema: Hukuk Muhakemeleri Kanunu'nun Zaman Bakımından Uygulanması, Ankara, 2013, s.167169; ARSLAN/YILMAZ/TAŞPINAR AYVAZ/HANAĞASI, s.63; PEKCANITEZ/ATALAY/ÖZEKES, Usûl, s.18; PEKCANITEZ, s.44-46; ATALI/ERMENEK/ERDOĞAN, s.24; TANRIVER, s.132.
} 
karara karşı kanun yolu açık olsa da kanun yolu yargılamasına nazaran daha hızlı, basit ve ucuz bir yol olarak hükmün tamamlanmasına başvurulması mümkün hale gelmiştir. $\mathrm{Bu}$ açıdan hükmün tamamlanması usûl ekonomisine hizmet etmektedir. Hükmün tamamlanması yolu, özellikle kesin olarak verilmiş veya kesinleşmiş yani kanun yoluna götürülemeyen nihaî kararlar bakımından önem arz eder. Böylece bu kararlarda eksik kalan hususların kanun yoluna başvurulamasa da tamamlanması etkin hukukî himayenin sağlanması bakımından oldukça faydalıdır.

Olumlu yönlerinin yanı sıra, hükmün tamamlanmasına ilişkin kanaatimizce eksik kalan konular bulunmaktadır. Bu noktalardaki eksiklikler ileride yargı kararları ile şekillenerek giderilebilir. Ancak kanun koyucunun ek kanunî düzenlemeler yapması daha uygun düşecektir. Bunlardan ilki, tamamlayıcı hükmün asıl hüküm karşısındaki hukukî niteliği hakkındadır. Hakem kararları bakımından verilen tamamlayıcı karardaki gibi (HMK m.437, V), tamamlayıcı hükmün, asıl kararın ayrılmaz bir parçası olduğu yönünde bir hüküm konulması kanaatimizce yerinde olacaktır. Böylece asıl hükme karş1 kanun yoluna yapılan başvuru ve verilecek karar bakımından ortaya çıkabilecek sorunlara bu kurala dayanılarak çözüm getirilebilecektir.

Hükümdeki eksiklik için hem istinaf kanun yoluna hem de hükmün tamamlanmasına başvurulması halinde, hükmün tamamlanması için ilk derece mahkemesinin vereceği kararı istinaf mahkemesinin beklemesine yönelik bir düzenleme yapılması da isabetli olacaktır. Kanaatimizce söz konusu durum, istinaf mahkemesinde Hukuk Muhakemeleri Kanunu'nun 360. maddesi gereğince bekletici sorun yapılmalıdır. Ancak uygulamaya açılık getirmek ve birbiri ile çelişen içtihatların ortaya çıkmasını önlemek bakımından açık bir kanunî düzenleme yapılmasında fayda bulunmaktadır.

\section{KAYNAKCA}

ALANGOYA, H. Yavuz/YILDIRIM, M.Kâmil/DEREN-YILDIRIM, Nevhis: Medeni Usûl Hukuku, 7. Bası, İstanbul, 2009.

ARSLAN, Ramazan/YILMAZ, Ejder/TAŞPINAR AYVAZ, Sema/HANAĞASI, Emel: Medenî Usûl Hukuku, 6. Bası, Ankara, 2020.

ATALI, Murat: Pekcanitez Usûl-Medenî Usûl Hukuku, C. III, İstanbul, 2017.

ATALI, Murat/ERMENEK, İbrahim/ERDOĞAN, Ersin: Medeni Usûl Hukuku, 3. Bası, Ankara, 2020.

BAHADIR, Zeynep: Medenî Usûl Hukukunda Kısmî Karar, Ankara, 2018.

BAUMBACH, Adolf/LAUTERBACH, Wolfgang: Becksche Kurz Kommentare Zivilprozessordnung, 62. Auflage, München, 2004.

BUDAK, Ali Cem/KARAASLAN, Varol: "7251 Sayılı Kanunla Hukuk Muhakemeleri Kanunu'nda Yapılan Değiş̧iklikler", İBD, 94 (5), 2020, s.15-50 (7251 Sayılı Kanun).

BUDAK, Ali Cem/KARAASLAN, Varol: Medenî Usûl Hukuku, 4. Bası, Ankara, 2020 (Usûl).

FASCHING, Hans W.: Kommentar zu den Zivilprozeßgesetzen, 2. Auflage, Wien, 2004.

GÖZÜTOK, Zeki/ALBAYRAK, Adem: Alfabetik Medeni Usul El Kitabı, Ankara, 2021.

Hukuk Muhakemeleri Kanunu ile Bazı Kanunlarda Değişiklik Yapılması Hakkında Kanun Teklifi (2/2735) ve Adalet Komisyonu Raporu, https://www.tbmm.gov.tr/sirasayi/donem27/yil01/ss216.pdf （Erişim tarihi: 1.10.2020).

KURU, Baki: Medeni Usûl Hukuku El Kitabı, C. II, Ankara, 2020.

MUSIELAK, Hans-Joachim: Kommentar zur Zivilprozessordnung, 8. Auflage, München, 2011.

ÖZTEK, Selçuk/TAŞPINAR AYVAZ, Sema/KALE, Serdar: "Hukuk Muhakemeleri Kanunu ile Bazı Kanunlarda Değişiklik Yapılması Hakkında 20 Mart 2020 tarihli Kanun Teklifi’ne İlişkin Bazı Açıklamalar ve Kanun Teklifinin Değerlendirilmesi”, TBBD, 149, 2020, s.77-152.

PEKCANITEZ, Hakan: Pekcanıtez Usûl-Medeni Usûl Hukuku, C. I, İstanbul, 2017.

PEKCANITEZ, Hakan/ATALAY, Oğuz/ÖZEKES, Muhammet: "Hukuk Muhakemeleri Kanunu'nda Değişiklik Yapılmasına Dair 7251 sayılı Kanun Hakkında Değerlendirme”, TBBD, 150, 2020, s.247-299 (7251 sayılı Kanun).

PEKCANITEZ, Hakan/ATALAY, Oğuz/ÖZEKES, Muhammet: Medenî Usûl Hukuku, 8. Bası, İstanbul, 2020 (Usûl). PRÜTTING, Hanns/GEHRLEIN, Markus: ZPO Kommentar, 2. Auflage, Köln, 2010.

RECHBERGER, Walter H./KLICKA, Thomas: Zivilprozessordnung, 5. Auflage, Wien, 2019.

ROSENBERG, Leo/SCHWAB, Karl Heinz/GOTTWALD, Peter: Zivilprozessrecht, 18. Auflage, München, 2018.

STAEHELIN, Adrian/STAEHELIN, Daniel/GROLIMUND, Pascal: Zivilprozessrecht, 2. Auflage, Zürich, 2013.

STEIN, Friedrich/JONAS, Martin: Kommentar zur Zivilprozessordnung, 22. Auflage, Tübingen, 2013.

TANRIVER, Süha: Medenî Usûl Hukuku, C. I, 3. Bası, Ankara, 2020.

TAŞPINAR AYVAZ, Sema: Hukuk Muhakemeleri Kanunu'nun Zaman Bakımından Uygulanması, Ankara, 2013.

THOMAS, Heinz/PUTZO, Hans: Zivilprozessordnung, München, 2016.

Türk Dil Kurumu Güncel Türkçe Sözlük, www.sozluk.gov.tr (Erişim tarihi: 10.12.2020).

UMAR, Bilge: Hukuk Muhakemeleri Kanunu Şerhi, 2. Bası, Ankara, 2014.

ÜSTÜNDAĞ, Saim: Medeni Yargılama Hukukunun Esasları, 7. Bası, İstanbul, 2000.

WIECZOREK, Bernhard/SCHÜTZE, Rolf A.: Zivilprozessordnung und Nebengesetze, Berlin, 2014.

YILMAZ, Ejder: Hukuk Muhakemeleri Kanunu Şerhi, C. III, Ankara, 2017. 